The Geological Society of America

Memoir 207

2011

\title{
Archean magmatic granulites, diapirism, and Proterozoic reworking in the Northern Marginal Zone of the Limpopo Belt
}

\author{
T.G. Blenkinsop \\ School of Earth and Environmental Science, James Cook University, Townsville QLD 4811, Australia
}

\begin{abstract}
The Northern Marginal Zone (NMZ) of the Limpopo Belt, southern Africa, is a high-grade gneiss belt dominated by magmatic granulites of the charnoenderbite suite, which intruded minor mafic-ultramafic and metasedimentary rocks between 2.74 and $2.57 \mathrm{Ga}$. The intrusive rocks have crustal and mantle components, and occur as elliptical bodies interpreted as diapirs. Peak metamorphism $(\mathrm{P} \leq \mathbf{8 0 0} \mathrm{MPa}, \mathrm{T}=$ $800-850{ }^{\circ} \mathrm{C}$ ) occurred at ca. $2.59 \mathrm{Ga}$. The highly radiogenic nature of the rocks in the NMZ, supplemented by heat from mantle melts, led to heating and diapirism, culminating in the intrusion of distinctive porphyritic charnockites and granites. Horizontal shortening and steep extrusion of the NMZ, during which crustal thickening was limited by high geothermal gradients, contrast with overthickening and gravitational collapse observed particularly in more recent orogens. The granulites were exhumed by the end of the Archean. The pervasive late Archean shortening over the whole of the NMZ contrasts with limited deformation on the Zimbabwe Craton, possibly owing to the strengthening effect of early crust in the craton. In the southeast of the NMZ, strike-slip kinematic indicators occur within the Transition Zone and the Triangle Shear Zone, where dextral shearing reworked the Archean crust at ca. 1.97 Ga.
\end{abstract}

\section{INTRODUCTION}

Exposed high-grade gneiss terranes afford direct insights into the nature of the mid- and lower crust. Archean examples are particularly fascinating because of the clues they contain about early Earth tectonics, which complement perspectives gained from the lower grade granite-greenstone terranes of Archean cratons (e.g., Fedo et al., 1995; Kreissig et al., 2000; Kisters et al., 2003). The issues of whether plate tectonics operated in the Archean (e.g., Hamilton 1998, 2003), when heat flow was 4-6 times present day values, and if so, how different it may have been, have been provoked by Limpopo studies (e.g., van Reenen et al., 1987; de Wit et al., 1992).

The Northern Marginal Zone (NMZ) is a high-grade gneiss terrane forming the northern part of the Limpopo Belt in southern Africa that illustrates several aspects of high-grade metamorphism. The terrane is $250 \mathrm{~km}$ long, with a maximum width of $70 \mathrm{~km}$, and located largely within southern Zimbabwe (Fig. 1). To the north lies the Archean Zimbabwe Craton, and to the south, the Central Zone of the Limpopo Belt, containing older

Blenkinsop, T.G., 2011, Archean magmatic granulites, diapirism, and Proterozoic reworking in the Northern Marginal Zone of the Limpopo Belt, in van Reenen, D.D., Kramers, J.D., McCourt, S., and Perchuk, L.L., eds., Origin and Evolution of Precambrian High-Grade Gneiss Terranes, with Special Emphasis on the Limpopo Complex of Southern Africa: Geological Society of America Memoir 207, p. 1-24, doi:10.1130/2011.1207(13). For permission to copy, contact editing @ geosociety.org. (C) 2011 The Geological Society of America. All rights reserved. 




Figure 1. The Northern Marginal Zone in the context of the rest of the Limpopo Belt and the Zimbabwe and Kaapvaal Cratons (adapted from Blenkinsop and Kisters, 2005). Box in NMZ indicates position of Figure 6.

and higher grade gneisses (e.g., Barton et al., 1994; Holzer et al., 1998; Kroener et al., 1998). In the southeast corner of Zimbabwe, metasedimentary rocks of the Umkondo Group (ca. $1100 \mathrm{Ma}$ ) and sedimentary and volcanic rocks of the Karoo System (Jurassic) overlie the gneisses. The NMZ is contiguous with the Matsitama-Motloutse Complex to the west in Botswana (McCourt et al., 2004), but this complex has some different characteristics from the rest of the zone, and so is not included in this study.

The NMZ has been divided into four major structural zones, as shown in Figure 1 (Blenkinsop et al., 1995; Kamber and Biino, 1995; Mkweli et al., 1995; Rollinson and Blenkinsop, 1995): the North Limpopo Thrust Zone at the contact with the Zimbabwe Craton, the Northern Marginal Zone sensu stricto (NMZ s.s.), the Transition Zone, and the Triangle Shear Zone at the contact with the Central Zone of the Limpopo Belt. These zones are defined mainly on the basis of tectonic fabrics, but they also have some distinctive petrological characteristics.

A brief review of early geological knowledge of the Limpopo Belt is given by Mason (1973). MacGregor (1953) identified the belt by name, and Cox et al. (1965) defined the marginal and central zones. The Geological Survey of Zimbabwe (formerly Rhodesia) played a major role in early studies of the NMZ, followed by researchers from the Universities of Leeds, Zimbabwe, and Bern. Despite some intensive pieces of research, large areas in the NMZ are known no better than at reconnaissance level: It is probably the least well studied part of the Limpopo Belt that is reasonably well exposed. Many studies generalize over the whole zone, and little attention has been paid to heterogeneity.

The aim of this chapter is to review the geology of the NMZ, emphasizing four inter-connected themes: the relationship of the NMZ to the Zimbabwe Craton, the formation of granulites, the role of Archean versus Proterozoic tectonics, and the exhumation of granulites. The review combines petrographic, structural, geochronological, and geochemical data acquired over the past $15 \mathrm{yr}$ with recent geophysical data, allowing a new understanding of high-grade metamorphic processes in this gneiss terrane, particularly in the late Archean.

\section{ROCK TYPES AND FIELD RELATIONSHIPS}

The rock types of the NMZ can be divided into a Supracrustal Assemblage that is intruded by a Plutonic Assemblage (Fig. 2; Rollinson and Blenkinsop, 1995). These assemblages are cut by discordant mafic dikes in several orientations, including the southern extensions of the Great Dyke and its satellites.

\section{The Supracrustal Assemblage}

The Supracrustal Assemblage consists of two main rock types: mafic granulites and metasedimentary rocks. The mafic 


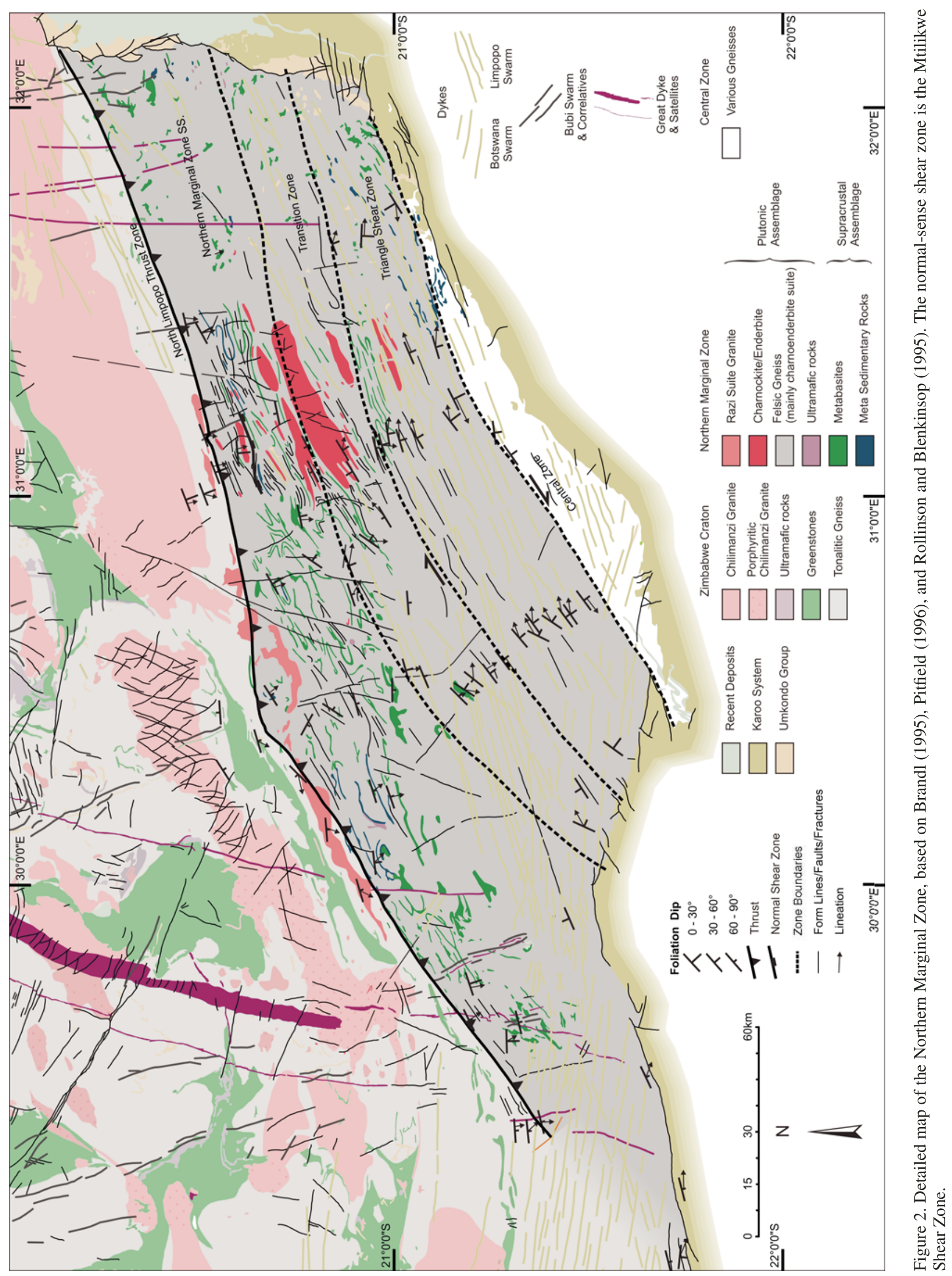


granulites comprise Opx, Pl, Hbl, Mag/Ilm \pm Bt, Cpx, Qtz (see Table 1 for mineral abbreviations), with variable grain sizes from less than one to several millimeters, and variable fabrics from massive to strong gneissic banding. The metasedimentary rocks are mainly banded iron formation sensu lato (s.l.), but include quartzite, magnetite quartzite, metapelite, calc-silicate, and marble (Kamber and Biino, 1995). Metapelite consists of Qtz, Bt, Opx, Grt, Sil \pm Crd, Ksp and shows evidence of partial melting. A single example of a coarse-grained marble ( $\mathrm{Cal}+\mathrm{Cpx})$ has been described (Mwatahwa, 1992). Calc-silicate rocks consist of Di, $\mathrm{Pl}, \mathrm{Qtz}, \mathrm{Am}, \mathrm{Ttn} \pm$ Grt. All metasedimentary rocks show evidence of strong deformation and low- to medium-pressure granulite facies metamorphism. Highly aluminous magnesium-rich granulite was described by Robertson (1973a) from the Mount Towla area, consisting of Opx, Ath, Spl, Spr, Crd, and Bt. The mafic granulites and the metasedimentary rocks typically form sheets a few tens of meters wide, subparallel to the dominant fabric of the NMZ (Fig. 2). In places they define spectacular kilometric isoclinal folds (Fig. 2). Metabasic rocks also form meter-scale inclusions within the Plutonic Assemblage rocks.

\section{The Plutonic Assemblage}

The vast majority of rocks in the NMZ are gray, green, or brown felsic granitoids and gneisses with grain sizes of millimeters to centimeters. Their mineralogy is Fsp, Qtz, Opx \pm Bi, Hbl, Cpx, Grt, with accessory Ap, Zrn, Fe-Ti oxides, and Py. These rocks have been almost always referred to as charnockite, charnoenderbite, or enderbite (e.g., Berger et al., 1995). The term charnoenderbite suite will be used to refer to the whole spectrum of compositions, which includes the specific type charnoenderbite.

Fabrics in rocks of the Plutonic Assemblage vary from undeformed, granular igneous textures to strong gneissic banding on a millimeter to centimeter scale. In places, strong fabrics are associated with grain size reduction, giving rise to protomylonites to mylonites (e.g., Blenkinsop and Kisters, 2005). Much of the Plutonic Assemblage occurs in oval bodies up to a few kilometers in size, partly to completely surrounded by supracrustal rocks, or in the cores of kilometer-scale, tight to isoclinal folds (Fig. 2: e.g.,
Blenkinsop et al., 2004). Various degrees of migmatization are recognized within the Plutonic Assemblage, resulting in either a distinctive massive white granitic rock with Grt, Mag, Sil, and Spl, which was called white granite by Rollinson and Blenkinsop (1995), or a coarser grained variety that occurs in obvious leucosomes parallel to the dominant east-northeast-trending fabric of the NMZ (Kamber and Biino, 1995).

An important debate concerns the interpretation of textures in these rocks. A magmatic origin for Opx is generally accepted (e.g., Berger et al., 1995), but opinions differ about the interpretation of some Bt textures. Bt is commonly found intergrown with Qtz. Ridley (1992) and Rollinson and Blenkinsop (1995) argued for magmatic crystallization of biotite (hydration crystallization) represented by:

$$
\mathrm{Opx}+\text { melt } \rightarrow \mathrm{Bt}+\mathrm{Qtz}
$$

as opposed to a retrograde hydration metamorphic reaction such as:

$$
\mathrm{Opx}+\mathrm{Kfs}+\mathrm{H}_{2} \mathrm{O} \rightarrow \mathrm{Bt}+\mathrm{Qtz}
$$

because of the following features: (1) lack of preferential growth of Bt and Qtz along Opx-Kfs boundaries, (2) lack of resorption of Kfs, (3) uniformity of texture, (4) vermicular Bt-Qtz texture, and (5) subhedral feldspars. Kamber and Biino (1995) disputed some of these interpretations on the grounds that Bt-Qtz intergrowths occur in strongly retrogressed rocks. Blenkinsop et al., (2004) recognized that both reactions can be present and that the first reaction could be distinguished because it produced delicate intergrowths of $\mathrm{Bt}$ and Qtz compared with the random textures owing to retrogression. The presence of the intergrowths in the absence of adjacent Kfs could also be taken as evidence for the first reaction.

At least two types of retrogression affect the felsic members of the Plutonic Assemblage to variable degrees. Zones of coarser grained, lighter colored rock ("granodioritic zones," Berger et al., 1995) were formed where $\mathrm{Pl}$ is replaced by Kfs from fluid ingress. In the second type, Opx is replaced by narrow zones of $\mathrm{Hbl}$ or Bt.

\begin{tabular}{|c|c|c|c|c|c|}
\hline Abbreviation & Mineral & Abbreviation & Mineral & Abbreviation & Mineral \\
\hline $\mathrm{Am}$ & Amphibole & Fo & Forsterite & PI & Plagioclase \\
\hline$A p$ & Apatite & Grt & Garnet & Px & Pyroxene \\
\hline Ath & Anthophyllite & Hem & Hematite & Py & Pyrite \\
\hline $\mathrm{Bt}$ & Biotite & $\mathrm{Hbl}$ & Hornblende & Qtz & Quartz \\
\hline Cal & Calcite & $\mathrm{IIm}$ & Ilmenite & $\mathrm{Rt}$ & Rutile \\
\hline Chl & Chlorite & Ksp & K-feldspar & Spr & Sapphirine \\
\hline Cpx & Clinopyroxene & Mag & Magnetite & Ser & Sericite \\
\hline Crd & Cordierite & Mc & Microcline & Sil & Sillimanite \\
\hline $\mathrm{Di}$ & Diopside & Ol & Olivine & Spl & Spinel \\
\hline Ep & Epidote & Or & Orthoclase & Ttn & Titanite \\
\hline Fsp & Feldspar & Opx & Orthopyroxene & Zrn & Zircon \\
\hline
\end{tabular}

TABLE 1. MINERAL ABBREVIATIONS* 
The youngest felsic member of the Plutonic Assemblage is a suite of late to post-tectonic granites and charnockites that are distinctive because of their large Ksp crystals. These porphyryitic granites were described as occurring in the Razi subprovince (around the contact between the craton and the NMZ), and in the Kyle subprovince (slightly to the north in the Zimbabwe Craton: Robertson, 1973a, 1973b, 1974), but following Rollinson and Blenkinsop (1995) they will be described here as the Razi suite. Fabrics vary from random to strong; the latter are magmatic fabrics commonly parallel to the general east-northeast trend throughout the NMZ (Fig. 2). These granites appear similar to the Chilimanzi granites of the Zimbabwe Craton. Their mineralogy varies from $\mathrm{Bt}+\mathrm{Hbl}$ near the Zimbabwe Craton (as in the Chilimanzi granites) to Opx dominant in the NMZ s.s., where they have a distinctive brown color. They are most common at the contact between the NMZ and the Zimbabwe Craton (the North Limpopo Thrust Zone), but there are also large bodies within the NMZ. The Razi suite is associated with pegmatites that are both parallel to and crosscut fabrics in the suite (e.g., Blenkinsop et al., 2004). Mafic minerals are generally not seen in the pegmatites, but up to $3 \% \mathrm{Bt}$ can occur.

Ultramafic rocks in the NMZ occur in association with mafic rocks (Fig. 2), for example, in the Towla, Neshuru, Sizire, Inyala, Crown, and Chingwa-Ma-Karoro complexes (Worst, 1962; Robertson, 1974; Odell, 1975). The ultramafic rocks consist of serpentinite, dunite, and pyroxenite, and chromite layers in some complexes were mined. The complexes appear to be at least partly intrusive on the basis of relict igneous textures (banding, cumulate textures).

\section{Mafic Dikes}

A variety of mafic dikes in at least four younger generations cuts other rocks in the NMZ (Fig. 2).

\section{The Great Dyke and Satellites}

The southern extension of the Great Dyke crosses the North Limpopo Thrust Zone continuously from the craton into the NMZ at the Umlali River (Robertson, 1973a; Figs. 1, 2). A satellite to the Great Dyke to the west (the Umvimeela Dyke) is also continuous across the craton-NMZ boundary, and a mafic dike to the east in the NMZ aligns with the East Dyke, a major satellite to the east of the Great Dyke on the craton (Figs. 1, 2). A north-south dike in the east of the NMZ (Fig. 2) that crosses into the Zimbabwe Craton (Fig. 2), and has a total strike length of $>100 \mathrm{~km}$, may be a satellite of the Great Dyke (Pitfield, 1996), with several other subparallel dikes.

\section{The Bubi Swarm}

Northwest- to north-northwest-trending dikes occur throughout the NMZ and the southern part of the Zimbabwe craton (Fig. 2). These have been called the Bubi swarm in the NMZ (Robertson, 1973a), and they are parallel to the Sebanga Poort
Dykes, considered to be coeval with the Mashonaland dolerites of the craton, intruded at ca. 2.0 Ga (Wilson et al., 1987).

\section{The Limpopo and Botswana Swarms}

East-northeast-trending dikes are abundant in the Triangle Shear Zone and the Transition Zone: These form the Limpopo Swarm (Fig. 2, Wilson et al., 1987). West-northwest-trending dikes in the southwest of the NMZ constitute the Botswana Swarm (Fig. 2), which intruded during the Jurassic Karoo igneous event (ca. $180 \mathrm{Ma}$ ), penecontemporaneously with the Limpopo Swarm (Reeves, 1978; Wilson et al., 1987).

\section{GEOCHEMISTRY}

Metabasites of the supracrustal assemblage range from basalt to trachyandesite in composition, and are olivine tholeiites by normative composition (Rollinson and Lowry, 1992). Rollinson and Lowry distinguished three types of metabasite from their REE (rare earth element) patterns: flat REE (A), enriched REE (B) and super-enriched REE (C): Fig. 3. A and B have similar patterns to tholeiites and calc-alkaline basaltic andesites of the Zimbabwe Craton, respectively. Three explanations were suggested for REE enrichment: crustal contamination, small degrees of partial melting, and source region heterogeneity. The first explanation was rejected because contamination with known local crustal compositions does not yield compatible major element compositions. The extreme enrichment of the group $\mathrm{C}$ dikes probably indicates an enriched mantle source (H. Rollinson, 2009, personal commun.). It is interesting that the Archean mafic dike geochemistry is similar to that of the Jurassic basalts of the Karoo igneous province in southern Africa (Rollinson and Lowry, 1992), which are also considered to be derived from an enriched mantle source (Duncan et al., 1984).

The major element geochemistry of the charnoenderbite suite classifies them mostly as tonalite (Fig. 4A), and there is a continuous compositional variation from these rocks to more felsic ones, including the granites of the Razi suite (Rollinson and Blenkinsop, 1995; Berger et al., 1995). Two features of the charnoenderbite suite geochemistry distinguish them from other Archean TTG (tonalite-trondhjemite-granodiorite) gneisses. They do not have depleted heat-producing elements (Th, U, Rb, K, Fig. 4B), and they are less sodic: Very few members of the charnoenderbite suite have trondhjemitic compositions (Berger and Rollinson, 1997; Fig. 4A).

Like the mafic rocks of the NMZ, the felsic rocks show fractionated light REE patterns (Fig. 4C), with fractionation increasing with $\mathrm{SiO}_{2}$ content (Rollinson and Blenkinsop, 1995). The fractionation is consistent with either melting of a garnet-bearing source rock, or garnet fractionation in the source. Element variation diagrams suggest that the members of the charnoenderbite suite are related by fractionation of $\mathrm{Cpx} / \mathrm{Opx}$, and $\mathrm{Hbl}$ or Plag \pm $\mathrm{Cpx} / \mathrm{Hbl}$ for the more felsic compositions (Berger et al., 1995). The Cpx fractionation trend indicates that the charnoenderbite 

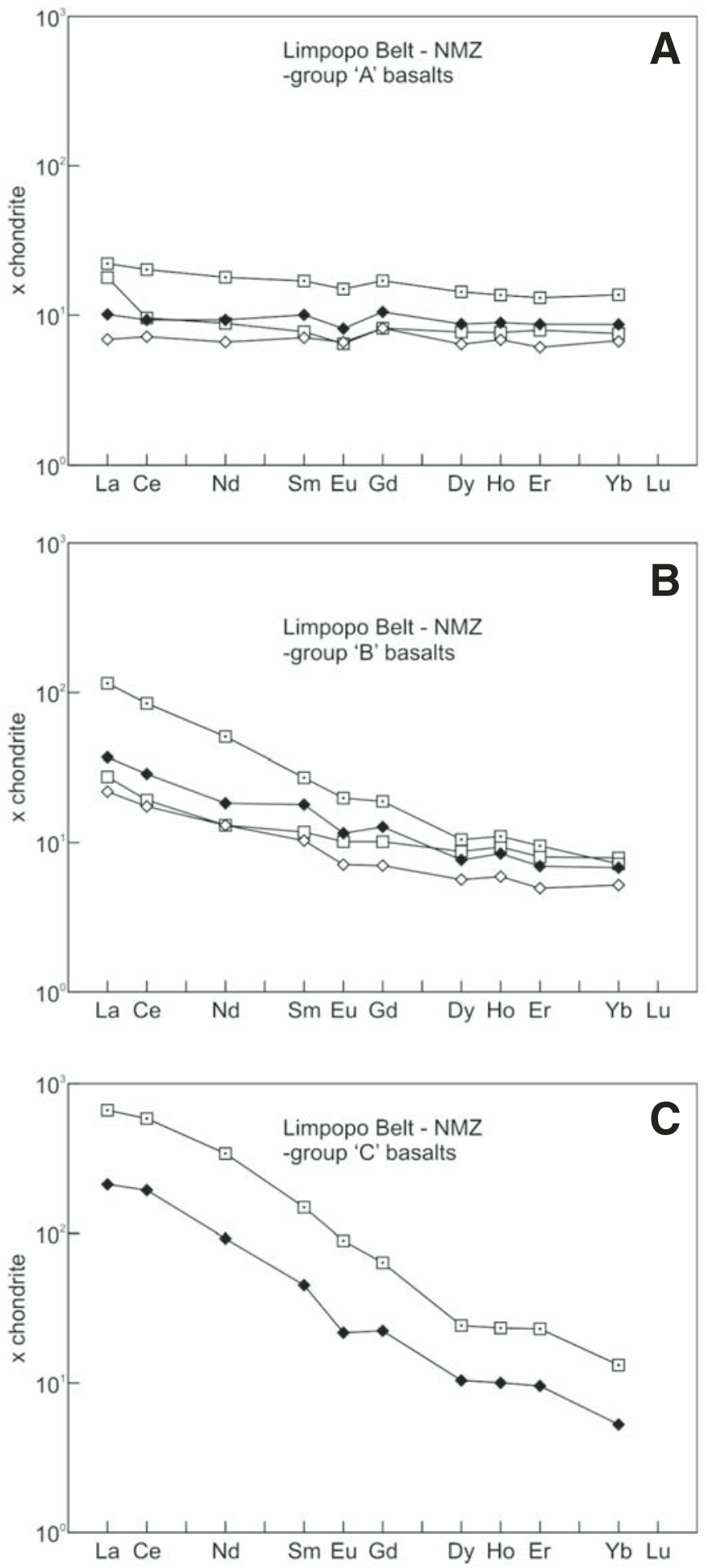

Figure 3. Rare earth element (REE) diagrams for three groups of metabasites from the NMZ (from Rollinson and Lowry, 1992). (A) Flat REE. (B) Enriched REE. (C) Super-enriched REE. REE enrichment may come from small degrees of partial melting or source region heterogeneity. suite is magmatic. Large ion lithophile (LIL) patterns of the Razi charnockites and granites fit trends of partial melting from enderbite compositions.

The geochemical trends of the plutonic assemblage have strong affinities to various gneisses and granites of the Zimbabwe Craton (Berger et al., 1995). Chingezi and Mashaba tonalites (Luais and Hawkesworth, 1994) have similar geochemical behavior to the charnoenderbite suite. The Chingezi and Mashaba type I rocks differ slightly from the charnoenderbite suite in having $\mathrm{Hbl}$ fractionation trends instead of Px (Berger et al., 1995). Chilimanzi suite granites from the craton follow Kfs fractionation trends from charnoenderbite compositions, which are compatible with their derivation by partial melting of enderbites, and higher level fractionation. This is consistent with the late to post-tectonic timing of these intrusives.

The geochemistry of chromites from ultramafic rocks in the NMZ was examined by Rollinson (1995a, 1995b, 1997). Chromites from the Rhonda ultramafic complex were compared to other chromite compositions to demonstrate that they may have preserved liquidus characteristics in the chromite cores, and a trend toward chromium enrichment from cores to rims of individual grains was attributed to the gain of $\mathrm{Cr}$ from igneous pyroxenes during granulite facies metamorphism (Rollinson, 1995a). The liquidus chromite compositions in the Rhonda and Inyala deposits indicate an ultramafic liquid source, similar to the source of komatiites in the Belingwe Greenstone Belt on the Zimbabwe Craton, and different from chromitites of the Bushveld and some other layered mafic intrusions (Rollinson, 1997). Olivine $\mathrm{Fo}-\mathrm{NiO}$ trends from the Inyala rocks are also continuous with Belingwe komatiites.

One of the most notable features of NMZ rock geochemistry as a whole are the very high Th and $\mathrm{U}$ contents (Berger et al., 1995; Berger and Rollinson, 1997). Kramers et al. (2001) calculated that the resulting heat production for the NMZ is comparable to, or exceeds by a factor of 2 , various estimates of heat production from the average upper crust. Rocks of the southern Zimbabwe Craton also have high Th and U contents, and would have generated slightly less heat $(80 \%)$ than the NMZ in the late Archean.

\section{METAMORPHISM}

\section{The North Limpopo Thrust Zone}

Metabasites in the southwest part of the North Limpopo Thrust Zone have a mineralogy of $\mathrm{Cpx}, \mathrm{Am}, \mathrm{Pl}, \mathrm{Bt} \pm$ Ttn, Ep, Ilm, Mag (Mkweli, 1997). An early high-grade assemblage of $\mathrm{Cpx}, \mathrm{Pl}, \mathrm{Am}$ is overgrown by Am, Bt, Mag, suggesting that the early $\mathrm{Cpx}$ has been replaced by $\mathrm{Am}$ and $\mathrm{Bt}$ in a retrogade event. This assemblage is in turn overgrown by Ep and Ttn. Both the early and the second assemblages are in the dominant foliation and appear to be syn-kinematic, but the Ep-Ttn retrogression is post-kinematic. Pressures have been estimated at 570-600 $\mathrm{MPa}$ and temperatures of $720-760{ }^{\circ} \mathrm{C}$ (Table 2). 



Figure 4. Geochemistry of the charnoenderbite suite, retrogressed rocks, and Razi granite suite (from Berger and Rollinson, 1997). (A) Normative An-Ab-Or classification diagram. The charnoenderbite suite is mainly tonalite. See (B) for key. (B) Mantle-normalized traceelement plots. Heat-producing elements $\mathrm{Th}, \mathrm{U}, \mathrm{Rb}, \mathrm{K}$ are not depleted, unlike other TTG (tonalite-trondhjemite-granodiorite) suites. (C) Chondrite normalized REE plots. The charnoenderbite suite has fractionated light REE patterns, like mafic rocks of the NMZ. 


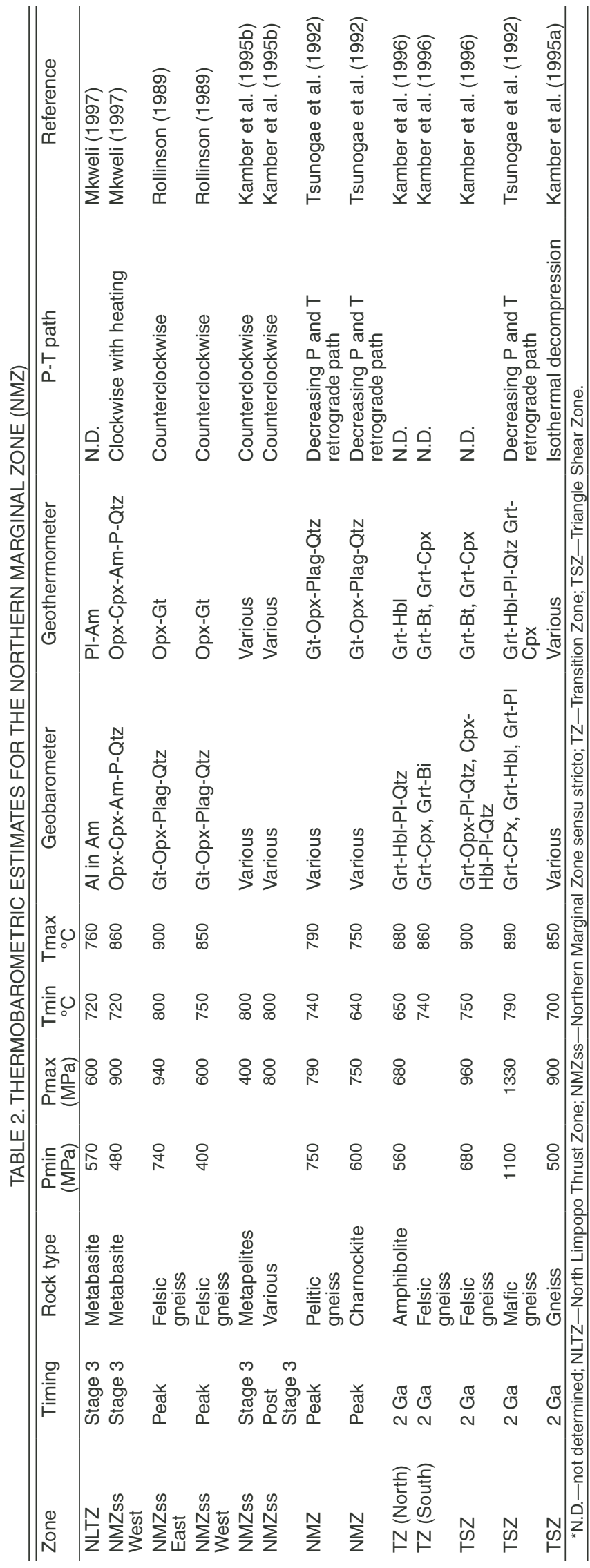

\section{The Northern Marginal Zone sensu stricto}

The detailed petrographic study of Kamber and Biino (1995) defined a four-stage metamorphic history for the NMZ s.s. Stages 1 and 2 are identified in metabasite enclosed within rocks of the charnoenderbite suite. Stage 1 has a mineralogy of $\mathrm{Pl}$, Opx, Cpx, Mag, and/or Ilm $\pm \mathrm{Hbl}$, Qtz and may have bands of alternating $\mathrm{Cpx}$ and Opx-rich compositions. Overgrowths of $\mathrm{Hbl}$ and Mag and/or Ilm on the pyroxenes defines the retrogressive Stage 2. Kamber and Biino (1995) suggest that metasedimentary rocks in the NMZ did not undergo Stages 1 and 2. However, banded iron formation is found in thin layers parallel to mafic granulite, a strong argument that these two rock types were formed at the same time and share a common metamorphic history.

A critical textural observation in these mafic granulites are prograde reactions around Stage $2 \mathrm{Hbl}$, which may be expressed as Opx and Pl symplectite on Hbl:

$$
\mathrm{Hbl}+\mathrm{Qtz} \rightarrow \mathrm{Pl}+\mathrm{Opx}+\mathrm{H}_{2} \mathrm{O},
$$

or:

$$
\mathrm{Hbl} \rightarrow \mathrm{Opx} \pm \mathrm{Cpx} \pm \mathrm{Pl}+\mathrm{Qtz} \pm \mathrm{Mag} / \mathrm{Hem}+\mathrm{H}_{2} \mathrm{O} .
$$

These textures indicate a second granulite facies event, Stage 3 (Kamber and Biino, 1995), which was the peak of metamorphism.

A somewhat different metamorphic history for the NMZ s.s. was reported by Mkweli (1997) for the southwest part of the domain. Here, the first assemblage in metabasites is a coarsegrained intergrowth of $\mathrm{Opx}$ and $\mathrm{Pl}$, which is interpreted to have grown after garnet during decompression heating. This is followed by an assemblage that is similar to Stage 1, which is overgrown by a symplectite of $\mathrm{Opx}, \mathrm{Cpx}, \mathrm{Pl}$, Mag that corresponds closely to the description of Stage 3 in Kamber and Biino (1995).

"Dehydration rims" have been described around metersized mafic xenoliths within the charnoenderbite suite rocks (e.g., Rollinson and Blenkinsop, 1995). These 1-cm-wide finer grained rims consist of $\mathrm{Opx}, \mathrm{Cpx}, \mathrm{Pl}, \mathrm{Bt}$, and Qtz. The presence of $\mathrm{Bt}$ distinguishes them from the Stage 3 reactions given above, and they are attributed to "partial host-xenolith equilibration in which a fluid was involved" by Kamber and Biino (1995), which may have been syn- to late- or post-magmatic.

Stage 3 in the charnoenderbite suite is manifest as various degrees of melting (Kamber and Biino, 1995), creating the migmatites described previously. Metamorphic conditions in Stage 3 are constrained to $>800{ }^{\circ} \mathrm{C}$ by reactions involving biotite breakdown of anhydrous pelitic assemblages, such as:

$$
\mathrm{Bt}+\mathrm{Sil}+\mathrm{Qtz} \rightarrow \mathrm{Kfs}+\mathrm{Grt}+\text { melt }
$$

$$
\mathrm{Bt}+\mathrm{Sil}+\mathrm{Qtz} \rightarrow \mathrm{Kfs}+\mathrm{Crd}+\text { melt }
$$


Peak metamorphic conditions of 740-940 MPa and 800$900{ }^{\circ} \mathrm{C}$ were measured in the eastern part of the NMZ s.s., and conditions of 400-600 MPa and $750-850^{\circ} \mathrm{C}$ for the western part (Table 2; Rollinson, 1989). A counterclockwise PT loop was established from changes in Grt compositions (Rollinson, 1989). Similar temperatures were established by Kamber et al. (1995b) and Kamber and Biino (1995). The latter study suggested that pressures rose during Stage 3 from $400 \mathrm{MPa}$ (suggested by the coexistence of $\mathrm{Spl}$ and $\mathrm{Crd}$ ) to a maximum near $800 \mathrm{MPa}$, constrained by the lack of garnet in mafic granulites (Fig. 5A). These authors were unable to confirm the suggestion by Rollinson (1989) that peak conditions were lower in the west, and proposed instead greater levels of post-peak metamorphic exhumation southward toward the Transition Zone and Triangle Shear Zone. Mkweli (1997) obtained similar peak P-T conditions to Kamber et al. (1995b) and Kamber and Biino (1995) from the southwest part of the NMZ, which also casts doubt on a systematic increase in grade from east to west. Mkweli's results did not show a systematic cross-strike variation in grade. Mkweli interpreted the $\mathrm{P}-\mathrm{T}$ path as generally clockwise, with intermittent heating events.

A different P-T path was proposed by Tsunogae et al. (1992). They suggested peak metamorphic conditions of 750-790 MPa and $740-790^{\circ} \mathrm{C}$, and linked them to lower grade conditions along a path of decreasing $\mathrm{P}$ and $\mathrm{T}$. Their approach was criticized by Kamber et al. (1996) and Kamber and Biino (1995), because the P-T path combined granulite facies rock from Stage 3 (Archean) metamorphism with amphibolite facies assemblages that may be Proterozoic in age (see below).

Stage 4 is a retrogression recorded by $\mathrm{Hbl}$ replacing Stage 3 Px, and by formation of Bt (Kamber and Biino, 1995; Mkweli, 1997). Such retrogression is confined to meter-decimeter-wide shear zones where $\mathrm{H}_{2} \mathrm{O}$ fluids were available. In the Razi granites, Stage 4 is marked by a greenschist facies assemblage of Ep, Am, $\mathrm{Ttn}, \mathrm{Ab}$, and Qtz within shear zones parallel to the main fabric. There appears to be an increase in Stage 4 metamorphic conditions toward the south: Bt changes from green-brown to reddish, and Am changes from hastingsitic $\mathrm{Hbl}$ to true $\mathrm{Hbl}$ (Kamber and Biino, 1995).

\section{The Transition Zone}

A significant proportion of rocks in the Transition Zone consists of Bt gneiss, lacking the Opx characteristic of the charnoenderbite suite in the NMZ s.s. Mafic rocks also lack a Px phase and are generally amphibolites. P-T conditions range from 560 to 680 $\mathrm{MPa}, 650^{\circ} \mathrm{C}$ at the boundary with the NMZ s.s., to $\sim 800 \mathrm{MPa}$ and $740-860^{\circ} \mathrm{C}$ at the boundary with the Triangle Shear Zone (Table 2 ), corresponding to the change from $\mathrm{Hbl}$ to two pyroxenes in mafic rocks from north to south across the Transition Zone.

\section{The Triangle Shear Zone}

Peak conditions of $1100-1330 \mathrm{MPa}$ and $790-890{ }^{\circ} \mathrm{C}$ were determined by Tsunogae et al. (1992) from a mafic gneiss using a

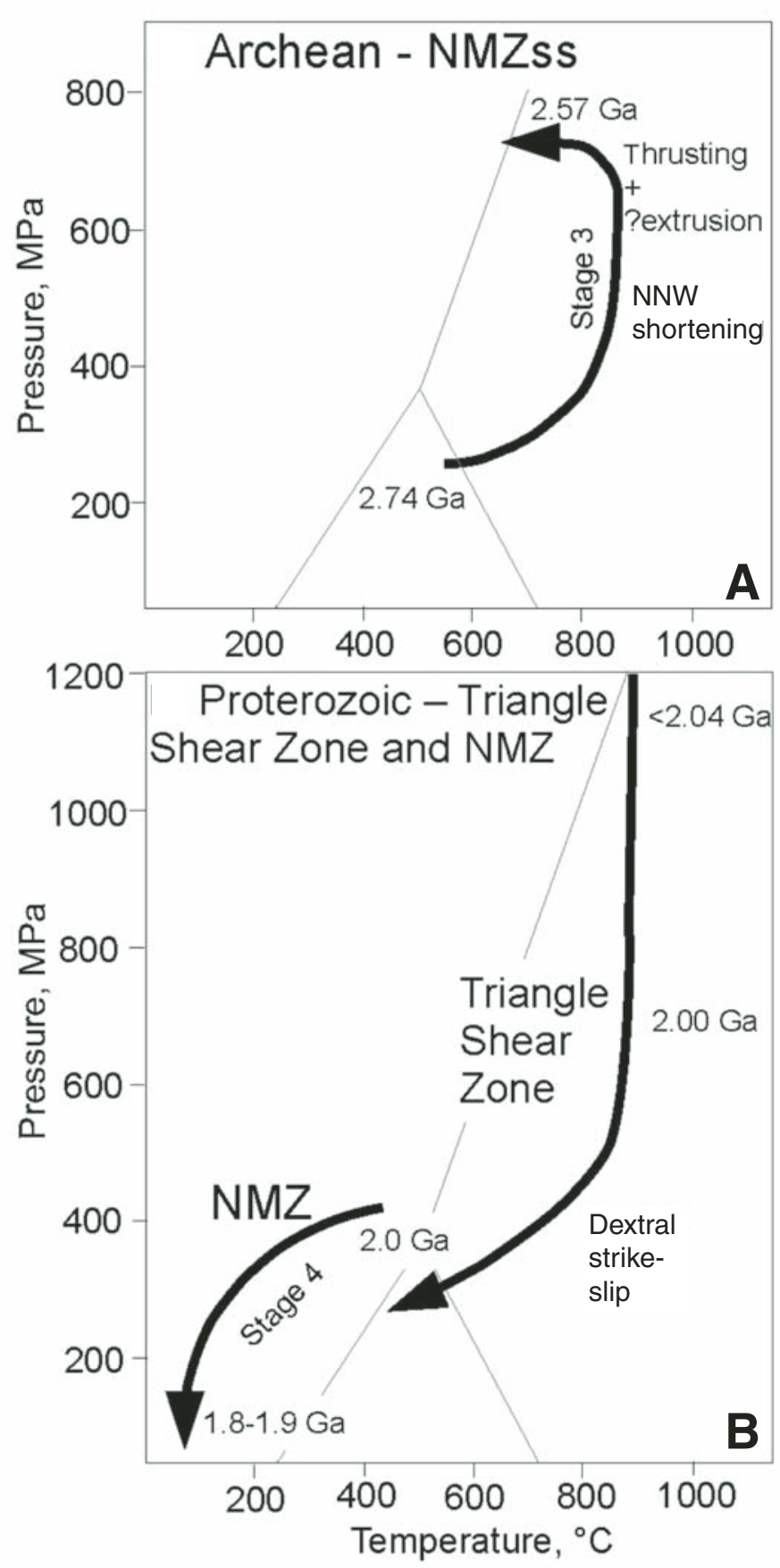

Figure 5. Pressure-temperature-time (P-T-t) paths and tectonics of Archean and Proterozoic events in the Northern Marginal Zone. (A) Archean P-T-t Stage 3 path of the NMZ s.s. from Kamber and Biino (1995). Stages 1 and 2 occurred some time before the start of Stage 3. (B) Proterozoic P-T-t paths of the NMZ (from Kamber and Biino, 1995) and the Triangle Shear Zone (from Kamber et al., 1995a; Tsunogae et al., 1992). The Proterozoic part of the NMZ path is Stage 4 of Kamber and Biino (1995). 
Grt-Cpx-Pl-Qtz assemblage (the location of this sample is reported as Central Zone but corresponds to the Triangle Shear Zone of this chapter). Near-isothermal decompression was inferred. Similar temperatures (700-850 ${ }^{\circ} \mathrm{C}$ ) were determined by Kamber et al. (1995a) for mylonitization, using a variety of mineral equilibria in felsic and mafic granulite and meta-melanosomes (Table 2), but the pressures were significantly lower (500-900 MPa) and similar to other determinations from Tsunogae et al. (1992). Pressure variations were interpreted as recording variations in exhumation during isothermal uplift, and a clockwise P-T path was inferred from textures such as coronas of Crd around Grt, and Pl around Grt (Fig. 5B; Kamber et al., 1995a).

\section{STRUCTURE}

\section{The North Limpopo Thrust Zone}

A zone of protomylonite and mylonite up to several kilometers wide marks the boundary in many places between greenschist-amphibolite-grade gneiss and greenstone of the Zimbabwe craton and the largely charnoenderbitic granulite of the NMZ s.s. (Blenkinsop et al., 1995; Mkweli, 1997). The mylonites dip moderately to the east-southeast and generally have a strong, almost perfectly downdip mineral stretching lineation, generally of Qtz (Fedo et al., 1995; Mkweli et al., 1995; Rollinson and Blenkinsop, 1995). Abundant shear sense indicators $(\sigma$ and $\delta$ porphyroclasts) show a reverse shear sense. The typical mineralogy of the mylonites is Qtz, Pl, Kfs, Bt $\pm \mathrm{Hbl}$, Ep, Ilm, Chl, Ttn, Ap, suggesting deformation in amphibolite to greenschist facies conditions. In places the contact between the craton and the NMZ s.s. is intruded by variably foliated granite of the Razi suite, and the zone of mylonites is obscured.

The reverse shear kinematics of the contact between the NMZ and the craton was recognized by Worst (1962), Robertson (1973a), James (1975), and Coward et al. (1976), but these workers suggested that the thrust did not exist along the SW half of the craton-NMZ contact in Zimbabwe. Mkweli et al. (1995) demonstrated that the thrust zone does extend along this part of the contact. The greater abundance of Razi granite intrusions in the southwest may be one reason that earlier workers did not recognize the existence of the thrust zone there. Mkweli (1997) showed that foliations in the thrust zone dip less steeply than in the craton or than the adjacent NMZ s.s., as expected in a reverse-sense shear zone. This variation was used to estimate the displacement on the thrust by strain integration, using the shapes of deformed clasts as an additional constraint. Considering the possibility of a pure shear component, and allowing for active as well as passive behavior of the foliation, all estimates of displacement are $<2 \mathrm{~km}$.

\section{The NMZ sensu stricto}

A pervasive fabric is found throughout the NMZ s.s., consisting of a millimeter- to centimeter-scale gneissic banding trending generally east-northeast, parallel to the strike of the NMZ, and dipping steeply south-southeast, or subvertical (Fig. 2). A parallel foliation is defined by grain shapes of Qtz, Pl, Kfs, and Hbl in many places. These minerals may also define a weak downdip mineral lineation.

Some of the most spectacular structures of the NMZ s.s. are tight to isoclinal, or elasticus, folds with wavelengths and amplitudes of kilometers, defined by folded layers of mafic granulite and banded iron formation (Fig. 2). The axial traces of the folds are parallel to the dominant east-northeast trend of the gneissic banding, which is, however, folded itself. The hinges of the folds plunge at variable angles to the eastnortheast or west-southwest. Elliptical bodies of charnockite and enderbite with dimensions of several kilometers also form prominent structures in the NMZ s.s. (Fig. 6). The long axes of the ellipses are parallel to the gneissic banding. These domal features are inferred to be diapiric in origin (Rollinson and Blenkinsop, 1995). Triangular shaped junctions of mafic granulites around the domes are similar in plan view to cleavage triple points, and some tabular bodies of mafic granulite may correspond to areas of flattening between domes (Fig. 6; cf. Brun et al., 1981).

Several different types of shear zones have been described within the NMZ s.s. (Kamber et al., 1996; Blenkinsop et al., 2004). These can be divided into four categories on the basis of inferred temperatures of deformation, relative timing, and kinematics, as follows.

\section{High-Grade Shear Zones}

A good example of this category is the Mtilikwe Shear Zone, a zone of protomylonite and mylonite at least

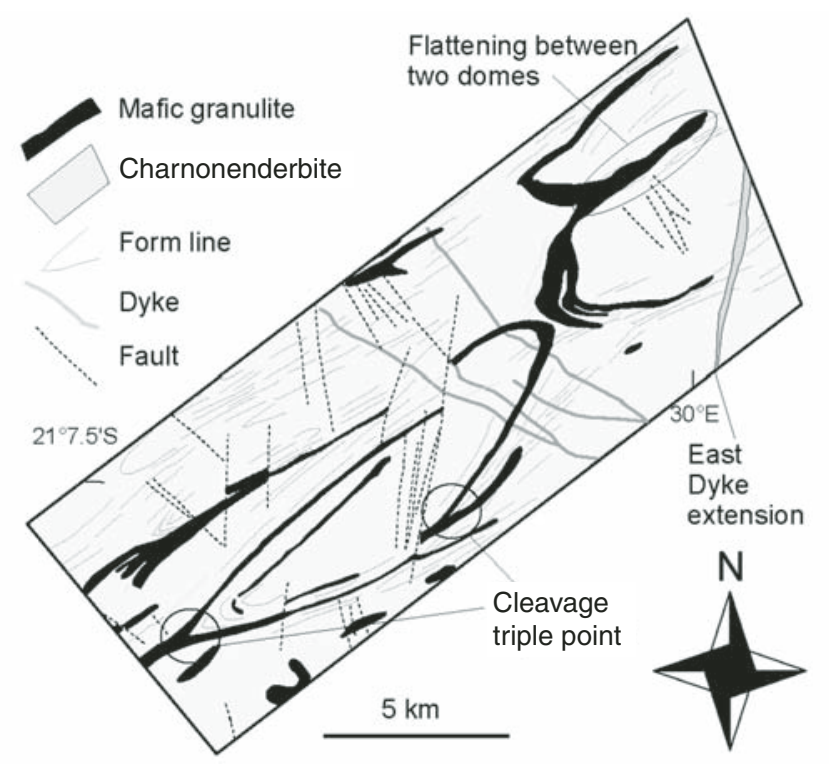

Figure 6. Geology of part of the NMZ, indicating features that could be interpreted as diapiric: domes, cleavage triple points (triangular junctions of mafic granulites), and tabular bodies of mafic granulite between two domes (from Mkweli, 1997). 
$25 \mathrm{~km}$ long and up to $500 \mathrm{~m}$ wide, $15 \mathrm{~km}$ south of the North Limpopo Thrust Zone (Blenkinsop and Kisters, 2005). The mylonitic foliation dips steeply south-southeast and carries a prominent downdip mineral lineation comprising mainly Qtz and Qtz-Fsp rods. Enderbitic protoliths of the mylonite comprise $\mathrm{Qtz}, \mathrm{Pl}, \mathrm{Bt}, \mathrm{Opx}$, and $\mathrm{Cpx}$, whereas charnockitic protoliths consist of Qtz, Mc, Or, Pl, Bt, Opx, and Cpx, and probable metasedimentary rocks have the same assemblage but with Grt and Sil instead of Px. Zr, Ap, Ilm, and Rt are common accessory minerals. All major phases except Grt are dynamically recrystallized, forming a fabric of Qtz and Fsp ribbon grains wrapping around porphyroclasts of Grt and Px. There is little evidence for retrogression.

The Mtilikwe Shear Zone is remarkable for a variety of clear shear-sense indicators that reveal a normal sense of movement. $\sigma$ and $\delta$ porphyroclasts and $\mathrm{SC}$ and $\mathrm{SC}^{\prime}$ fabrics are common. Extension microfractures in Grt porphyroclasts filled by Qtz, Fsp, and Bt of the main mineral assemblage have a consistent orientation that also indicates normal movement. $\mathrm{A} \mathrm{Pb}-\mathrm{Pb}$ step leach age of $2601 \pm 5 \mathrm{Ma}$ for a synkinematic garnet dates the age of deformation in this shear zone (Blenkinsop and Frei, 1996), compatible with a late Stage 3 timing, as suggested by the mineralogy.

\section{Medium-Grade Shear Zones}

Meter-decimeter-wide shear zones parallel to the eastnortheast trend of the NMZ were described by Kamber and Biino (1995), Kamber et al. (1996), and Blenkinsop et al. (2004). These shear zones form an anastomosing network with a strong $\mathrm{S}>\mathrm{L}$ fabric defined by Qtz, Bt, and Fsp, dipping gently to moderately south-southeast with a downdip mineral lineation. $\sigma$ and $\delta$ porphyroclasts generally indicate reverse shear. Pl shows deformation twinning, Mc has well-developed undulatory extinction, and oriented myrmekite intergrowths occur at the ends of Pl porphyroclasts. Grt has ubiquitous microfractures and Qtz pressure shadows. These microstructural features indicate deformation at the upper end of the $400-500{ }^{\circ} \mathrm{C}$ range, and suggest formation as Stage 3 waned.

\section{Strike-Slip Shear Zones}

The gneissic banding in the NMZ s.s. and in the North Limpopo Thrust Zone is cut and deformed by a system of discrete shear zones, typically several meters long and a few centimeters wide (Blenkinsop and Mkweli, 1992). These shear zones have consistent orientations and kinematics over the whole of the NMZ: They are vertical and trend either northwest or north-northeast. They contain Qtz-Pl-Kfs mylonite with subhorizontal lineations, and locally they are intruded by granitic pegmatite that is also deformed. The gneissic foliation of the NMZ is deformed by these shear zones. The northwest- and north-northeast-trending shear zones are invariably dextral and sinistral, respectively, as shown by the deflection of gneissic banding, and no crosscutting relationships are seen between the two sets. These features are all consistent with formation of the shear zones as conjugate sets with a north-northwestshortening direction, contemporary with the intrusion of the granitic pegmatites. The contemporaneous intrusive activity suggests that these shear zones were part of Stage 3. Fractures in similar orientations to these shear zones are a conspicuous feature in the Chilimanzi granites of the southern margin of the Zimbabwe Craton (Fig. 2; Robertson, 1973b).

\section{Low-Grade Shear Zones}

Low-grade shear zones are $10 \mathrm{~cm}-2 \mathrm{~m}$ wide with a maximum strike length of $350 \mathrm{~m}$, separated by $3-5 \mathrm{~km}$ both along and across strike. They have been described from the area around the Renco gold mine (Blenkinsop et al., 2004). They are parallel to the trend of the NMZ, and some occur along parts of the medium-grade type of shear zone, although they are much shorter and narrower. They are characterized by cataclastic textures with centimeter-sized fragments separated by narrow fractures. Qtz is fractured, $\mathrm{Pl}$ is altered to $\mathrm{Chl}$ and Ttn, and $\mathrm{Mc}$ to Ser, Ep, and Chl. Am and Px are entirely replaced by Chl and Ttn. Lack of lattice deformation in feldspar suggests temperatures of deformation $<400{ }^{\circ} \mathrm{C}$. Features suggestive of pseudotachylite have been described for these shear zones. The shears were interpreted as Proterozoic in age by Blenkinsop et al. (2004), and they are similar to shear zones described by Kamber et al. (1996) that correspond to Stage 4.

An important problem posed by these shear zones is their kinematics. Kamber et al. (1996) were unable to find shearsense indicators within these shear zones but inferred a thrust sense from feldspar clasts in the surrounding gneisses, and from asymmetric folds. Likewise, Blenkinsop et al. (2004) could not find reliable shear-sense indicators. However, Kolb et al. (2003) reported evidence for normal-sense movement on shear zones at the Renco mine, which they describe as occurring at or below $300{ }^{\circ} \mathrm{C}$ on shear zones dipping gently southeast.

\section{The Transition Zone}

The transition from the NMZ s.s. to the Triangle Shear Zone is marked by the appearance of moderately southeast-dipping foliation with lineations plunging gently to the southwest. This foliation occurs in localized zones that increase in abundance toward the south (Kamber et al., 1995b). Fabrics in the Transition Zone therefore consist of alternating zones where the foliation preserves downdip lineations typical of the NMZ s.s., and zones where the lineations are subparallel to strike. There is an overall decrease in foliation dip to the southeast within the Transition Zone, and there are also asymmetric folds with subhorizontal hinges on meter to kilometer scales, which consistently verge to the northwest. Fabrics are generally $\mathrm{S}>\mathrm{L}$. No indications of non-coaxial deformation are seen on a small scale. Fabrics within the Transition Zone have been interpreted as indicating a zone of northwest shortening and subvertical extension by Kamber et al. (1995b), associated with the $2.0 \mathrm{Ga}$ orogeny in the Central Zone of the Limpopo Belt. This interpretation is supported by 
MWR207-13 1st pgs page 12

$\mathrm{Hbl} \mathrm{Ar-Ar} \mathrm{ages} \mathrm{from} \mathrm{both} \mathrm{the} \mathrm{downdip} \mathrm{and} \mathrm{strike} \mathrm{subparallel} \mathrm{ori-}$ entations (Table 3).

\section{The Triangle Shear Zone}

In the Triangle Shear Zone the southeast dip of the foliations observed in the Transition Zone is pervasive (James, 1975). As defined by Rollinson and Blenkinsop (1995), the zone has a strike length of at least $140 \mathrm{~km}$ and a width of $30-50 \mathrm{~km}$ (Figs. 1,2 ), characterized by intense mylonitic L-S fabrics (Kamber et al., 1995b) with subhorizontal Qtz and Fsp mineral lineations. Grain sizes are half those of the Transition Zone. The majority of mylonite has a Qtz, Ksp, $\mathrm{Pl}, \mathrm{Bt}, \mathrm{Opx}, \mathrm{Hbl} \pm \mathrm{Grt}$ mineralogy and is clearly derived from the charnoenderbite suite. Rocks consisting of $\mathrm{Bt}, \mathrm{Grt}, \mathrm{Sil} \pm \mathrm{Crd}, \mathrm{Spl}$ are interpreted as Al-rich melanosome in migmatites, with leucosome of Qtz, Ksp, Pl, Grt, and Fe-Ti oxides. Metabasic rocks consist of $\mathrm{Cpx}, \mathrm{Opx}, \mathrm{Pl}, \mathrm{Grt}, \mathrm{Hbl} \pm \mathrm{Qtz}$. Quartzite, calc-silicate and metapelite have also been reported from the Triangle Shear Zone (Ridley, 1992; Rollinson and Blenkinsop, 1995). Surfaces perpendicular to the foliation and parallel to the lineation show excellent and consistent shear-sense indicators in the form of $\sigma$ and $\Delta$ clasts and rolling structures, always indicating dextral shear.

The Triangle Shear Zone changes in strike from eastnortheast in the eastern part of the NMZ to northeast in the central part, where it is obscured by Karoo cover. It does not coincide with the Tuli-Sabi Shear Zone shown in McCourt and Vearncombe $(1987,1992)$, nor does the Magogaphate Shear Zone in Botswana (e.g., McCourt et al., 2004), or any other mapped shear zone, appear to be continuous with the Triangle Shear Zone. The nature of the boundary between the NMZ and the Central Zone in the west of the NMZ is therefore still problematic.

\section{GEOPHYSICS}

Resistivity, gravity, aeromagnetic, seismic-reflectionrefraction, receiver-function, and shear-wave-splitting studies that include the NMZ have been carried out over the Limpopo Belt, as summarized below. The results of geophysical studies have been important in formulating tectonic models for the Limpopo Belt, especially in view of the large portion that is covered. Unfortunately the geophysical database for the whole belt is still rather sparse.

One of the first large-scale geophysical studies of the Limpopo Belt was a deep resistivity profile carried out by Van Zijl (1978). Results were interpreted to indicate a flat Moho at a depth of $\sim 40 \mathrm{~km}$ under both cratons and the belt, at the base of a hydrated lower crust.

Coward and Fairhead (1980) presented a gravity map of the Limpopo Belt that had few stations in the NMZ. Relatively positive Bouguer values under the Southern Marginal Zone were interpreted as a fold above a ramp in a north-verging, crustalscale thrust. North vergence was also interpreted in the Central Zone and the NMZ, where granulite was shown as thrusting over the Zimbabwe Craton on a contact dipping at $10^{\circ}$ south. The concept of a north-verging collisional structure had considerable influence on subsequent concepts for the tectonic evolution of the Limpopo Belt (e.g., Roering et al., 1992; Treloar et al., 1992).

The earliest geophysical study focused on the NMZ specifically was a refraction seismic survey (Stuart and Zengeni, 1987), which suggested Moho depths of 40 and $34 \mathrm{~km}$ under the Zimbabwe Craton and the NMZ, respectively, and that the NMZ crust thins from 34 to $29 \mathrm{~km}$ under the Triangle Shear Zone. The Craton-NMZ boundary was considered to be a steeply dipping feature, in contrast to the moderate dips of structures seen at the surface, and fast traveltimes were interpreted to indicate some high-velocity material along the boundary, possibly the Buhwa Greenstone Belt. The idea of a steep boundary between the NMZ and the craton also influenced tectonic models (e.g., Rollinson, 1989; Ridley, 1992).

The detailed work of Gwavava et al. $(1992,1996)$ on gravity of the Limpopo Belt challenged both of these earlier studies. A much larger database of gravity stations was available, which give a negative Bouguer anomaly of the same order of magnitude under the craton and the NMZ. These data imply that there is no change in the Moho depth of $34 \mathrm{~km}$ across the boundary between the craton and the NMZ. Admittance and coherence studies by Gwavava et al. (1996) using the same gravity data recognized a zone of negative isostatic anomalies in the NMZ, which may have resulted from uncompensated recent erosion.

Receiver-function studies from the Kaapvaal Craton seismic experiment (James, 2003) suggested different results from the gravity and previous seismic studies for the crustal structure of the Limpopo Belt. Unfortunately only a single station in the experiment was on the NMZ itself. The results indicate that the Zimbabwe Craton has crustal thicknesses of 35-40 km (Nguuri et al., 2001; Niu and James, 2002; Stankiewicz et al., 2002; Nair et al., 2006) and that the NMZ has a crustal thickness of $37 \mathrm{~km}$, the same as the adjacent Zimbabwe Craton, within error. These results are supported by shear-wave-velocity profiles obtained by joint inversion of receiver functions and Rayleigh wave group velocities (Kgaswane et al., 2010).

Receiver functions can also be used to find the Poisson's ratio of the crust, which is typical of felsic-intermediate compositions for the cratons and intermediate-mafic compositions for the Limpopo Belt. The shear-wave velocities from joint inversion suggest that most of the lower $10 \mathrm{~km}$ of crust under the NMZ is mafic in composition (Kgaswane et al., 2010). This contrasts with the western part of the Tokwe terrane on the Zimbabwe Craton, where the lower crust has intermediate compositions. Receiver functions can also be used to quantify the sharpness of the Moho (Nair et al., 2006). This reveals that the Moho is less well defined under the NMZ than the craton.

The Kaapvaal Craton seismic experiment also gave some insights into mantle structure below southern Africa. The cratons and the Limpopo Belt are underlain by high-velocity zones with thicknesses of 250-300 km, visible in tomographic images (James et al., 2001; James and Fouch, 2002; Fouch et al., 2004), 


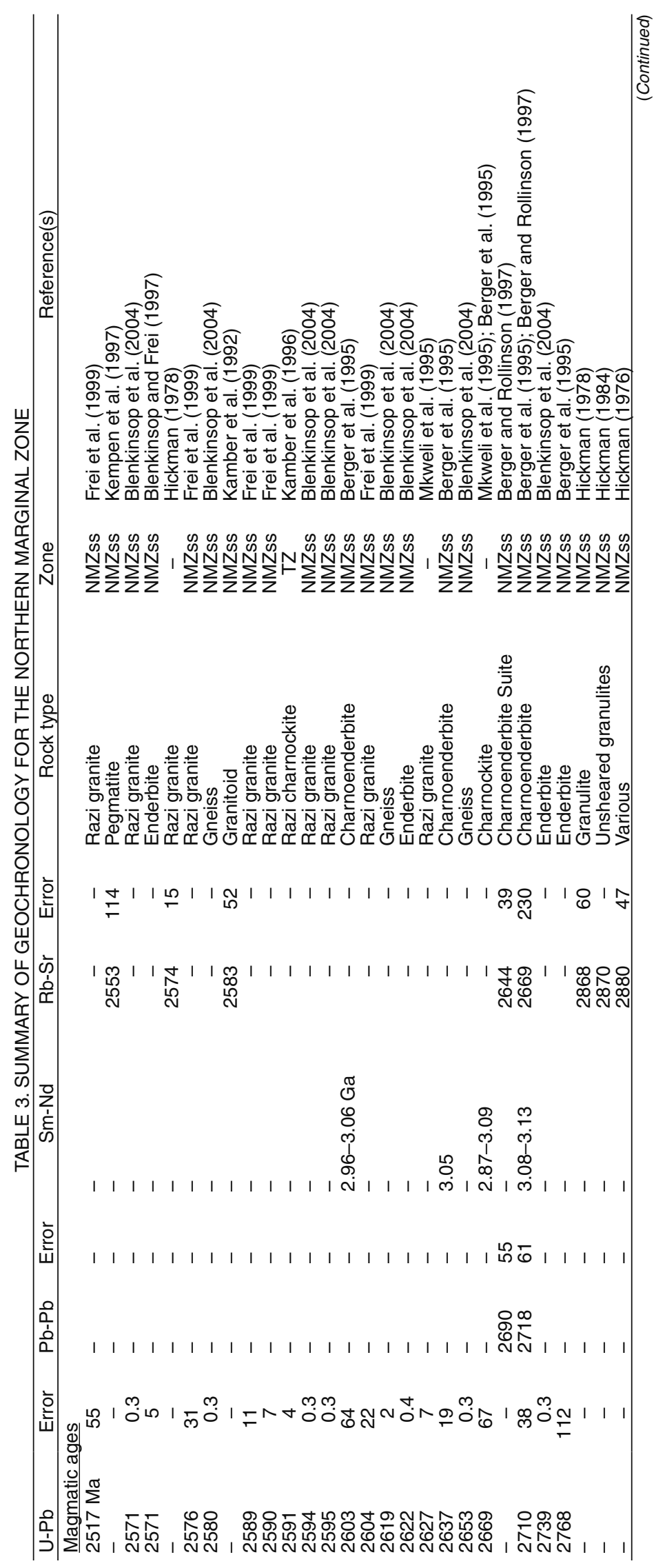




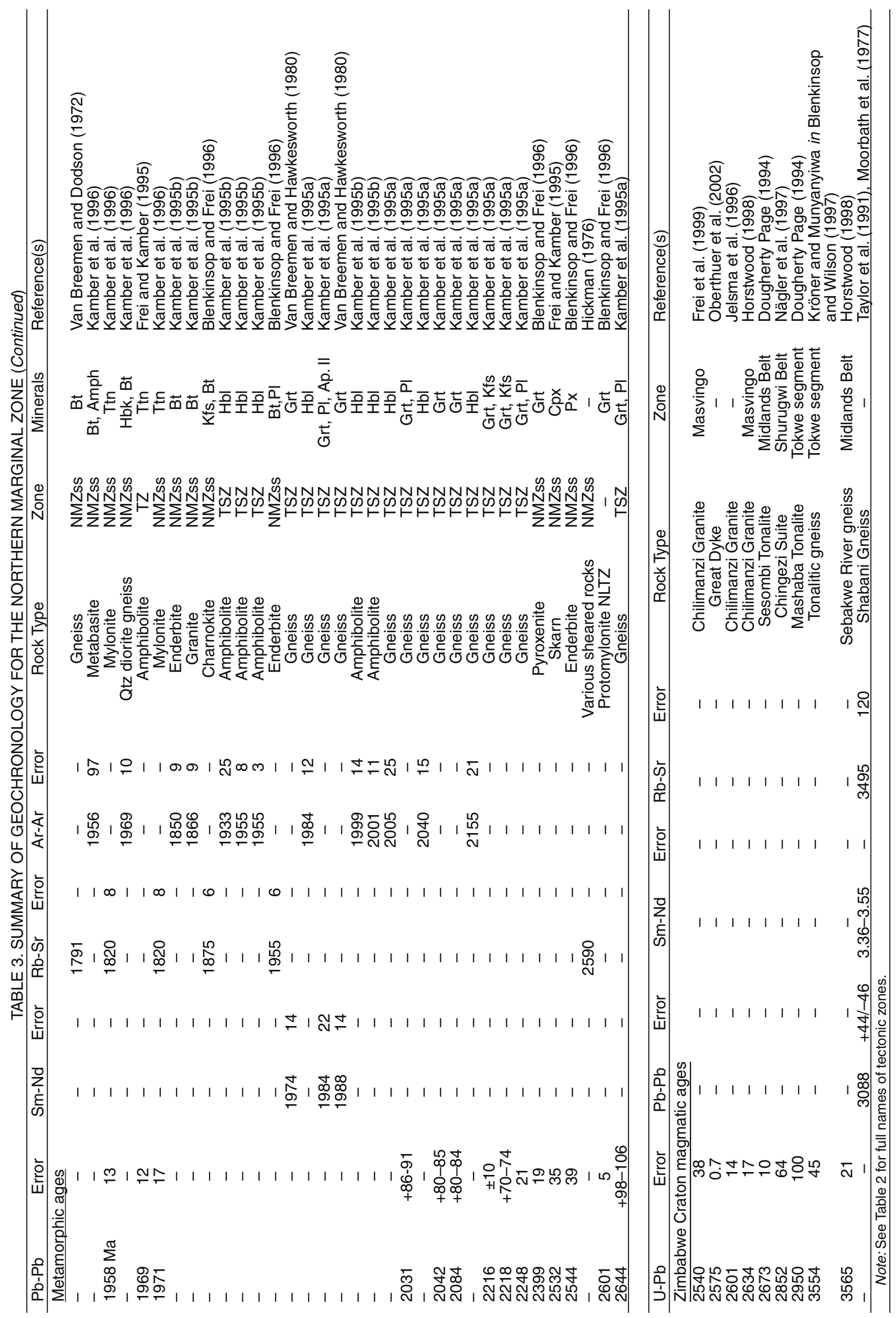


which correspond to the "tectosphere" of Jordan (1975). Despite the significant differences in the crust of the cratons and the Limpopo Belt suggested by the experiment, the mantle seems to be similar under both: This conclusion is also supported by the joint inversion work (Kgaswane et al., 2010). McKenzie and Priestley (2008) show that the thickness of the lithosphere underneath the cratons is similar to that under the Limpopo Belt. James and Fouch (2002) interpreted the formation of the tectosphere as a result of depletion in subduction-related melting events during the Archean to form high-velocity mantle roots to depths of at least $200 \mathrm{~km}$.

Shear-wave-splitting measurements reveal one difference between mantle under the Zimbabwe Craton and under the NMZ: The azimuths of fast polarization directions on the craton in Zimbabwe are approximately north-northeast, subparallel to the Great Dyke, whereas the NMZ station has a NW azimuth $\left(336^{\circ}\right)$, quite different from the craton, and from the northeast to east-northeast direction of the rest of the Limpopo Belt (Silver et al., 2001). The origin of the anisotropy is considered to lie in the mantle at depths of no greater than $50-100 \mathrm{~km}$, and is clearly different from the direction predicted by modern movements of the African plate. The mantle anisotropy is interpreted to reflect Archean deformation patterns, both on the craton, where an earlier anisotropy was exploited by intrusion of the Great Dyke, and in the Limpopo Belt (Silver et al., 2004). It is difficult to evaluate the significance of the single NMZ shear-wave-splitting result within the NMZ: Such a northwest direction corresponds to the ca. 2.0 Ga Bubi swarm, but as pointed out by Silver et al. (2004), it is unlikely that dikes themselves can produce the necessary shear-wave anisotropy.

In summary, most geophysical evidence suggests that the NMZ has a similar crustal thickness to the Zimbabwe Craton, 35-37 km. However, the lower part of the NMZ crust seems to have a more mafic composition and a less-well-defined Moho than part of the craton. The single shear-wave-splitting result gives a different direction in the NMZ from the craton, but the mantle beneath the cratons, the NMZ, and the rest of the Limpopo Belt is otherwise rather similar and constitutes a tectosphere.

\section{GEOCHRONOLOGY}

The study of rocks from the NMZ has played a significant role on the world stage in the development of geochronological techniques. The first ever Sm-Nd ages were obtained from rocks in the Triangle Shear Zone (Van Breemen and Hawkesworth, 1980), and rocks from the NMZ s.s. were used by Frei and Kamber (1995) to establish the $\mathrm{Pb}-\mathrm{Pb}$ step leach method. Significant advances in understanding the geochronology of granulite facies rocks were taken by Kamber et al. (1996, 1998), who demonstrated from studies in NMZ rocks that partial resetting below commonly accepted closure temperatures may occur in Grt, Hbl, and $\mathrm{Zr}$. The influence of ionic porosity on Ar-Ar dates was investigated by Kamber et al. (1995b). Despite these pioneering studies, there have so far not been any SHRIMP zircon age determi- nations from the NMZ. The vast majority of $\mathrm{U}-\mathrm{Pb}$ studies have been via the TIMS method, with some Kober ages (Table 3 and references therein).

Charnoenderbite suite and Razi suite granites have highly consistent $\mathrm{T}_{\mathrm{DM}}$ ages of ca. 3.0 Ga (Berger et al., 1995). The oldest ages that are interpreted as magmatic from the $\mathrm{NMZ}$ are $\mathrm{Rb} / \mathrm{Sr}$ whole rock isochrons from granulite gneiss at ca. $2870 \mathrm{Ma}$ (Hickman, 1978, 1984; Table 3). These determinations were the first geochronological studies carried out in the belt, but they remain unique. The closest age by any other method is a $\mathrm{U} / \mathrm{Pb}$ Zircon date 100 m.y. younger (Table 3).

Ages interpreted to be magmatic (mostly U-Pb zircon) are in the range $2.8-2.5 \mathrm{Ga}$, including crystallization of the charnoenderbite suite and the intrusion of the related Razi suite granites (Fig. 7; Table 3). Taking the dates at face value, the charnoenderbite suite formed between 2768 and $2571 \mathrm{Ma}$, and the Razi suite granites intruded between 2637 and 2517 Ma (Table 3 and references therein). The ages at the extremes of this range have large errors: A better constrained estimate for the intrusion of the charnoenderbite suite is 2739-2571 Ma, and for the Razi suite granites, 2627-2571 Ma. There is a clear overlap in ages between the two groups of rocks, with the Razi suite granites intruding toward the end of the charnoenderbite suite time interval (Fig. 7), consistent with the field observations that the Razi suite granites show little or no fabric, or magmatic fabrics, and that some Razi suite granites apparently intrude the charnoenderbite suite rocks.

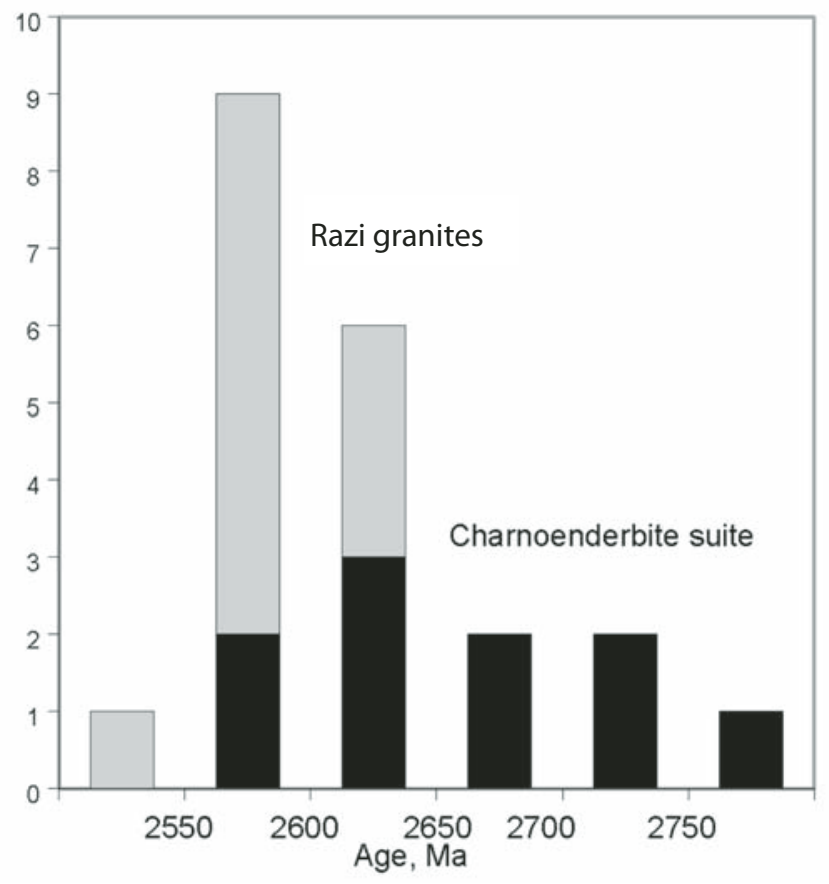

Figure 7. Histograms of U-Pb zircon ages, divided into the charnoenderbite suite and the Razi granites. Data and sources from Table 3. There is a clear overlap of the charnoenderbite and Razi suites, with the latter intruding toward the end of the former. Dates at the extreme ends of the spectrum have very large errors. 
The Razi suite granites appear to have intruded diachronously, younging from west to east (Frei et al., 1999). The only magmatic rocks of early Proterozoic age in the NMZ may be the Bubi swarm dikes (Wilson et al., 1987).

Dates from the NMZ that are interpreted to reflect metamorphic mineral growth fall into two major groups: late Archean and early Proterozoic. The syntectonic charnockite intrusion age of $2591 \pm 4$ Ma obtained by Kamber et al. (1996) in the Transition Zone was regarded as timing peak Archean (Stage 3) metamorphism and is similar to a garnet $\mathrm{Pb}-\mathrm{Pb}$ age in a protomylonite obtained by Blenkinsop and Frei (1996), and within error of a $\mathrm{Pb}-\mathrm{Pb}$ age from the Triangle Shear Zone (Kamber et al., 1995a). Slightly younger, late Archean ages are given by minerals from samples in the NMZ s.s. (Frei and Kamber, 1995; Blenkinsop and Frei, 1996).

The importance of early Proterozoic ages in the NMZ was recognized by the pioneering $\mathrm{Sm} / \mathrm{Nd}$ study of Van Breemen and Hawkesworth (1980) but was largely overlooked in subsequent studies (Kamber et al., 1995a). The combined data from $\mathrm{Pb}-\mathrm{Pb}$, $\mathrm{Sm}-\mathrm{Nd}, \mathrm{Rb}-\mathrm{Sr}$, and Ar-Ar studies now indicate a plethora of early Proterozoic metamorphic ages, from 2084 to $1956 \mathrm{Ma}$ (Table 3). The older part of this spectrum comes exclusively from the Triangle Shear Zone and records a granulite facies event with dextral strike-slip movement (Kamber et al., 1995a). Ar- $\mathrm{Ar}$ and $\mathrm{Pb}-\mathrm{Pb}$ ages in the NMZ s.s. are interpreted as recording a short period of exhumation at $1.97 \mathrm{Ga}$ (Kamber et al., 1996).

Four $\mathrm{Pb}-\mathrm{Pb}$ dates and one $\mathrm{Ar}-\mathrm{Ar}$ date fall between the Archean and Proterozoic groups (Table 3). These dates have been interpreted as partial resetting of minerals in the Proterozoic event by Kamber et al. (1996).

\section{DISCUSSION}

\section{Relationship of the NMZ to the Zimbabwe Craton and Archean Tectonics}

There are several notable similarities between the geology of the NMZ and the Zimbabwe Craton. Both have a majority of felsic intrusive igneous rocks with a minority of mafic rocks (although there is a greater proportion of mafic rocks on the craton at the surface), and the range of tonalitic-granodioritic pluton compositions is similar. The occurrence of thin mafic units associated with metasedimentary rocks around the felsic plutons in the NMZ has its counterpart in the arrangement of granites and greenstones in the Zimbabwe Craton, and the large intrusive bodies in the NMZ are echoed by the "gregarious batholiths" of the Zimbabwe Craton (MacGregor, 1951). Diapirism has been invoked as an important process in both the craton (e.g., Jelsma et al., 1993) and the NMZ (e.g., Rollinson and Blenkinsop, 1995). Geochemical affinities between mafic and felsic rocks in the NMZ and craton have been emphasized by Rollinson and Lowry (1992), Berger et al. (1995), and Berger and Rollinson (1997).

Moreover, there are similarities in the geochronology of the NMZ with the Zimbabwe Craton, which was comprehen- sively compiled by Jelsma and Dirks (2002). The consistent ca. 3.0 Ga Sm-Nd age of charnoenderbite suite rocks in the NMZ (e.g., Berger et al., 1995) is similar to Sm-Nd ages of the Chingezi Tonalite (Taylor et al., 1991). The late Archean ages of the charnoenderbites overlap with zircon dates of the Sesombi suite (Dougherty-Page, 1994), and the Razi granite ages correspond closely to the range of dates for the Chilimanzi granites (e.g., Jelsma et al., 1996; Horstwood, 1998; Frei et al., 1999). It is notable that the age of the Great Dyke $(2575 \pm 0.7 \mathrm{Ma}$; Oberthür et al., 2002) shows that it predates some Chilimanzi and Razi suite granites, suggesting that the Great Dyke intruded before final cratonization.

One conspicuous difference between the craton and the NMZ is the lack of reliable crystallization ages greater than 2768 Ma, or $2739 \mathrm{Ma}$ using better constraints (Table 3). Older Rb-Sr dates from Hickman (1978) are similar to U-Pb zircon dates of the Chingezi suite (Table 3; e.g., Nägler et al., 1997). Although the $\mathrm{Rb}-\mathrm{Sr}$ dates could relate to cratonic events, such dates have never been demonstrated from U-Pb work in the NMZ, which instead suggests a major crust-forming period from 2.74 to $2.57 \mathrm{Ga}$. No counterparts of the ca. $2.95-3 \mathrm{Ga}$ or ca. $3.5 \mathrm{Ga}$ ages from the craton have been found, despite isotopic evidence for older crust being involved in charnoenderbite suite genesis (Berger and Rollinson, 1997). The extent to which the difference between NMZ and craton geochronology is a sampling issue may be addressed by comparing the 53 crystallization ages reported from the craton (Jelsma and Dirks, 2002) with 28 magmatic ages from the NMZ (Table 3).

Another major difference between the craton and the NMZ is the presence of a widespread penetrative fabric in the NMZ, which reflects north-northwest shortening in the late Archean. Regional shortening in a similar direction occurred on the craton (Blenkinsop et al., 1997; Wilson et al., 1995) but had a much weaker expression. Understanding this difference in late Archean mechanics of the craton and the NMZ is a significant challenge. An explanation could be sought in the mantle. One difference between the subcratonic mantle and that beneath the NMZ is the shear-wave-splitting direction (Silver et al., 2001), although the NMZ orientation is based on a single measurement. In other respects there appear to be no major variations in geophysical properties of the subcontinental lithospheric mantle between the NMZ and the craton today (James and Fouch, 2002). This observation agrees with the inference from Re-Os systematics that the subcontinental lithospheric mantle under the craton and NMZ has a similar history, involving episodes of growth from $3.8 \mathrm{Ga}$ through the Archean (Nägler et al., 1997). Hence, mantle explanations for the difference between the craton and the NMZ may be inadequate.

The oldest part of the Zimbabwe craton (the Tokwe segment, $3.6 \mathrm{Ga}$ ) abuts the NMZ, and the presence of xenocrystic zircons predating all of the granite-greenstone cycles on the craton suggests that early crust was widespread there (Wilson et al., 1995). Possibly a greater abundance of old crust strengthened the craton relative to the NMZ in the late Archean. Alternatively 
or additionally, the higher heat generation of the rocks in the NMZ may have caused greater thermal weakening of its crust. A crustal explanation of the difference between the late Archean events in the craton compared with the NMZ is likely in view of the inference that the lower $10 \mathrm{~km}$ of the NMZ is more mafic than the craton (Kgaswane et al., 2010). This material could partly comprise supracrustal rocks such as those on the Zimbabwe Craton, which have been entrained downward by more complete convective overturn than on the craton (see below).

A striking feature of the NMZ s.s. is the consistency of the moderate to steep dips of the main foliation. There are no flatlying foliations or recumbent folds that might indicate gravitational collapse, a feature that is increasingly seen as typical of orogenesis (e.g., Rey et al., 2001). Instead, the combination of normal-sense movement on shear zones such as the Mtilikwe Shear Zone, thrusting on the North Limpopo Thrust Zone, and horizontal shortening with steeply plunging extension, suggests subvertical extrusion in the northern part of the NMZ (Blenkinsop and Kisters, 2005). This is consistent with a more rigid Zimbabwe Craton. The lack of gravitational collapse also implies a lack of overthickening by thrusting, which may be characteristic of Archean orogeny (e.g., Choukroune et al., 1995). The distinctive features of the late Archean orogeny in the NMZ partly reflect the high heat flow of the late Archean and thus offer some insights into secular changes in orogenic style (cf. Marshak, 1999).

The shortening that generated the penetrative fabrics in the NMZ and was responsible for thrusting the NMZ over the Zimbabwe Craton has been attributed to convergence between the Zimbabwe and Kaapvaal Cratons (e.g., McCourt and Vearncombe, 1987; van Reenen et al., 1987; de Wit et al., 1992; Treloar et al., 1992), although details have been debated (e.g., Treloar and Blenkinsop, 1995). Hallmarks of a Himalayan-type continental collision are absent from the Limpopo Belt: A suture cannot be identified, and the polarity of subduction cannot even be clearly defined. This may be due to overprinting by Proterozoic events. Thus there are still fundamental questions about the geodynamics of late Archean events in the Limpopo Belt, which include the possibility of intracontinental orogeny.

\section{Formation of Granulite}

Most of the rocks in the NMZ are magmatic granulites of the charnoenderbite suite, associated with low- to medium-pressure granulite facies metamorphism. Three alternative models are discussed for formation of the granulites: an arc-backarc origin, the MARCY model of Kramers (1988), and radiogenic heating leading to diapirism.

Higher heat flow in backarc regions has been suggested as an explanation for the mechanical difference between "mobile belts" and cratons by Hyndman et al. (2005), and backarcs are identified as a locus of granulite facies metamorphism by Collins (2002). Berger and Rollinson (1997) offered an Andean setting for comparison with the NMZ on the basis of evidence for crustmantle interaction during crustal growth. However, the possibil- ity that the NMZ was a backarc attached to a stable craton during Stage 3 granulite formation is contradicted by the late Archean tectonics of the Zimbabwe Craton, which did not become fully cratonized until the end of the Archean (Wilson, 1990). Arc and backarc settings are indeed sometimes invoked for the greenstone sequences of the Zimbabwe Craton itself (e.g., Jelsma and Dirks, 2002). An intraoceanic arc setting for the NMZ is denied by $\mathrm{Nd}$ compositions of charnoenderbite suite rocks, which are between +1 and $-2 \varepsilon_{\mathrm{ND}}$, compared with predicted values of +3 for $2.7 \mathrm{Ga}$ intraoceanic island arcs (Berger et al., 1995).

The differences in metamorphic pressure estimates between the craton and the NMZ are taken as reflecting an original $15 \mathrm{~km}$ increase in crustal thickness in the NMZ by Ridley (1992), which should have contributed to an increased geothermal gradient in the NMZ. Lack of evidence for such a geotherm suggested to Ridley (1992) that the crust was thickened in the NMZ with a mantle heat-flow value lower than today's value. Such a mantle heat sink could occur above a mantle downwelling zone, which is also part of the MARCY (MAntle ReCYcling) model of Kramers (1988) and Kramers and Ridley (1989) for the formation of low- to medium-pressure granulite in the NMZ by crystallization from the base of a shallow, partially molten zone. TTG compositions such as those of the charnoenderbite suite can form by crystallization of a magma reservoir being continuously recharged by tholeitic magma from the mantle. Hydration crystallization reactions such as described above are predicted if the magma reservoir is hydrated, which might occur by incorporation of hydrothermally altered crust into the magma reservoir. This model can also generate the light REE enriched geochemistry of the charnoenderbite suite, and predicts that water activity would be buffered at low values.

The low value of the mantle heat flux required in the MARCY model is incompatible with the thermal modeling of Kramers et al. (2001), nor is the former model commensurate with the $\mathrm{Nd}$ isotopic evidence that requires mixing between mantle melts and preexisting continental crust (Berger and Rollinson, 1997). As described above, there is no record of an anomalous zone in the mantle below the NMZ today (James et al., 2001; James and Fouch, 2002) that might record a previous subduction event, such as is seen in the Superior province (e.g., White et al., 2003).

A different scenario for granulite facies metamorphism in the NMZ is suggested by Kramers et al. (2001), who demonstrate that lower crustal melting and advective heat flux could occur, given the high heat production of the NMZ rocks. This alternative for a source of heat for metamorphism is favored over crustal thickening because of the geochemical evidence of Berger and Rollinson (1997) that a mantle component was involved in charnoenderbite suite magmatism. The geochemical evidence for mantle input could indicate that mantle melts were an additional heat source. Widespread evidence for diapirisim in the NMZ s.s. accords well with this model (e.g., Fig. 6), which can also explain the variability in P-T conditions and paths reported for the NMZ s.s., because different parts of a diapiric system can undergo different P-T conditions and trajectories 
(e.g., Collins and Van Kranendonk, 1999). Mkweli (1997) considered that convection was an appropriate mechanism to explain not only variable P-T conditions in the NMZ s.s., but also the apparent small displacement on the North Limpopo Thrust Zone. In a convective model (either magmatic or solid state), large temperature differences can occur across boundaries that would not necessarily record large tectonic translations.

Diapirism involves at least two positive feedback loops, decompression melting and downward entrainment of fertile source rocks (Weinberg, 1997). These processes can generate multiple pulses of heat advection, allowing the system to maintain plutonism for long periods, and they may go some way toward explaining the $\sim 200$ m.y. duration of the charnoenderbite suite and Razi granite magmatism. Gerya et al. (2004) showed that hot continental crust may become inherently gravitationally unstable.

Diaprisim is one component of the convective overturn model of the crust proposed by Collins and Van Kranendonk (1998), in which diapiric rise of material is complemented by sinking of higher density greenstone material. Partial or complete convective overturn is likely to have played a role in the $\mathrm{NMZ}$ in order to explain the thorough mixing of the charnoenderbite suite protoliths, which occurred throughout their formation (Berger and Rollinson, 1997). The mafic lower crust of the NMZ (Kgaswane et al., 2010) is consistent with this model: It may represent both the accumulation of denser material during convective overturn and mantle intrusions. The latter may be the reason for the less-well-defined Moho under the NMZ than the craton (Nair et al., 2006).

The formation of granulites in the NMZ from heat advection in diapirs as part of a convective system, driven by internal heating, possibly with additional heat from mantle melts, is an attractive hypothesis that is consistent with diverse sets of observations. It differs from other mechanisms for granulite facies metamorphism in not requiring anomalous thicknesses of crust, for which there is no direct evidence, and which is consistent with the lack of gravitational collapse features.

\section{Archean versus Proterozoic Tectonics in the NMZ}

Although the tectonics of the NMZ were considered entirely Archean in several earlier studies (e.g., Coward et al., 1973; McCourt and Vearncombe, 1987; Coward and Treloar, 1990; Rollinson, 1993), geochronological results clearly indicate the importance of the $2.0 \mathrm{Ga}$ event in the Triangle Shear Zone (e.g., Van Breemen and Dodson, 1972; Kamber et al., 1995a), which features in more recent tectonic models (e.g., Treloar and Blenkinsop, 1995; Kamber et al., 1995b, 1996). A lateral component of movement in the Proterozoic was recognized by Roering et al. (1992) and van Reenen et al. (1987), and subsequent studies reflected the growing appreciation of the significance of the Proterozoic event in the Central Zone (e.g., Barton et al., 1994; Holzer et al., 1998, 1999). What remains controversial for the NMZ, however, is the extent to which it has been reworked in the
Proterozoic. The problem is considerably compounded because tectonics of the Proterozoic event in the northern part of the NMZ were apparently identical to the late Archean event: Both involve purely reverse movement on southeast-dipping shears (e.g., Blenkinsop et al., 2004).

Mineral ages of ca. $1.97 \mathrm{Ga}$ in fabric-defining Hbl (Kamber et al., 1995b) are reasonable evidence that the Proterozoic event had an important impact on the Transition Zone. Other Proterozoic mineral ages in the NMZ s.s. are mainly from $\mathrm{Bt}$ and Ttn phases with lower closure temperatures, confined to meter- to decimeter-wide shear zones (Kamber et al., 1996). If these ages represent a deformation event, its significance depends on the density and distribution of these shear zones, and the displacements along them. Such shear zones are described by Kamber et al. (1996) for the Chiredzi River, but it is difficult to evaluate their tectonic significance from cross-strike profiles alone, which do not reveal their strike-parallel dimensions or spacing. The low-temperature shear zones described above have strike lengths limited to a few hundred meters and are separated by several kilometers (Blenkinsop et al., 2004). Since linking structures have not been observed between these shear zones, it is not likely that large regional strains have been accommodated on them.

An additional constraint on the tectonics of the NMZ is placed by the geometry of the southern extension of the Great Dyke and its satellites (Figs. 1, 2). Kamber et al. (1996) suggested that the dike was displaced parallel to its intersection with shear zones trending $\sim 100^{\circ}$ (which they had measured from the eastern part of the NMZ s.s.), and therefore did not have a mapped separation. They further argued that sinistral separations of the northwest-trending "East Dyke" were compatible with thrusting, and used these separations to derive an estimate of $10 \mathrm{~km}$ of vertical displacement at ca. 2.0 Ga. However, no such thrust structures have been observed in the field cutting the Great Dyke extension, and it is also likely that the northwest-trending dike is part of the Bubi-Sebanga Poort set of dikes (e.g., Pitfield, 1996). Mineral ages, remagnetization of the Great Dyke (Mushayandebvu et al., 1994), retrogression, and isolated low-temperature shear zones are all compatible with only limited deformation in the NMZ during the $2.0 \mathrm{Ga}$ event. There is also the possibility that extensional structures (e.g., Kolb et al., 2003) occurred at this time.

The debate about Archean versus Proterozoic tectonics in the NMZ s.s. is reflected in the controversy over the ages of hydrothermal mineralization at the Renco gold mine, which is $\sim 10 \mathrm{~km}$ south of the North Limpopo Thrust Zone. Proterozoic greenschist facies mineralization was proposed by Blenkinsop and Frei $(1996,1997)$, but Kisters et al. $(1997,1998,2000)$ and Kolb et al. (2000, 2003) argued that mineralization was related to late Archean, amphibolite facies conditions, shortly after peak metamorphism. Blenkinsop et al. (2004) proposed that the controversy could be resolved by recognizing that there were indeed two phases of deformation at the mine, in the late Archean and early Proterozoic, respectively, but that if mineralization occurred at high temperatures, as suggested by the thermometry of Kisters et al. (1997), then it was likely to have been late Archean. 


\section{Exhumation of the NMZ}

The amount of displacement in the Proterozoic is critical to understanding exhumation mechanisms in the NMZ and other high-grade gneiss terranes. Modeling suggests that granulites that form in the lower plate of an orogen, or in a single plate, are not exhumed by isostasy in a single event but require a second orogeny (Ellis, 1992). This two-phase exhumation history has been documented (e.g., Harley, 1989), and Kamber et al. (1996) suggested that the $2.0 \mathrm{Ga}$ event (Stage 4) in the NMZ led to the final exhumation of the NMZ granulites. Integral to this argument is the suggestion that the Archean crust was never $>45 \mathrm{~km}$ thick; otherwise the granulites would have been exhumed isostatically.

Several arguments against a two-phase exhumation history for the NMZ have been made. Continuity of deformation from granulite through to amphibolite facies deformation along the North Limpopo Thrust Zone is suggested by Ridley (1992), and through to greenschist facies by Mkweli et al. (1995). The lack of deformation of the Great Dyke was taken as evidence against two-stage exhumation by Blenkinsop et al. (2004), who also cited the preservation of prograde textures in granulites, which should not exist if the rocks have cooled at depth (Ellis, 1992). There are no empirical constraints on the thickness of the Archean crust to allow resolution of this issue by recourse to isostatic arguments. A comparison with the Southern Marginal Zone of the Limpopo Belt is interesting: there, thrusting of the Southern Marginal Zone over the Kaapvaal Craton occurred exclusively in the Archean over the period 2690-2600 Ma (Kreissig et al., 2001). There has been no suggestion of a Proterozoic event to exhume the Southern Marginal Zone granulites.

The history of exhumation in the NMZ can be completed with new data pertaining to Cretaceous to recent events from apatite fission-track analysis. These indicate a cooling (exhumation) event from 130 to $90 \mathrm{Ma}$, corresponding to removal of $1.3-2 \mathrm{~km}$ material, and a second event in post-Cretaceous time, in which $0.8-1 \mathrm{~km}$ of exhumation occurred (Belton, 2006). A third event may also have occurred in the Paleogene. The first event has been linked to the opening of the South Atlantic (Belton, 2006), and all three may correspond to the formation of epeirogenic uplift axes (Partridge and Maud, 1987; Moore et al., 2009). These Phanerozoic exhumation episodes therefore may have contributed $3 \mathrm{~km}$ of differential exhumation between the NMZ and the craton, although this does not seem compatible with the abundance of crater-facies blocks in the River Ranch kimberlite in the Central Zone (Muusha and Kopylova, 1998).

\section{Outstanding Challenges in Northern Marginal Zone Geological Research}

Few studies have examined along-strike variations in the character of the NMZ. The lack of clarity about the nature of the $\mathrm{NMZ}$ to the west is a major impediment to relating the NMZ to the rest of the Limpopo Belt. The boundaries of the Central Zone have been defined on the basis of the Tuli-Sabi or Triangle Shear
Zone, but there is no continuity between shear zones mapped in Botswana and the Triangle Shear Zone, leaving a major gap in our understanding of the surface geometry of the Limpopo Belt. Unfortunately the area is poorly exposed or covered by Karoo deposits. The suggestion, on the basis of gravity results by Ranganai et al. (2002), that the Limpopo Belt continues as the Shashe Belt to the west in Botswana, with no Proterozoic overprint, has major implications for the issue of the westward continuation of the NMZ.

The extent of Proterozoic reworking in the NMZ s.s. is still not resolved and requires systematic detailed mapping of wellexposed areas where the length, continuity, separation, and possibly displacements across low-grade structures can be evaluated. This is a target for future research, which would preferably encompass areas at contrasting ends of the NMZ to allow evaluation of strike variations.

Understanding the relation between the Zimbabwe Craton and the NMZ may offer the most acute insights into Archean tectonics. A systematic search for a pre- 2.7 Ga history in the NMZ, which is hinted at by various isotopic evidence (Berger and Rollinson, 1997; Nägler et al., 1997), would be a starting point, possibly involving SHRIMP dating. This would confirm how far back into the Archean the craton and the NMZ may have a common history. An important additional step is to integrate the NMZ and Zimbabwe Craton tectonic histories to those of the rest of the Limpopo Belt and the Kaapvaal Craton (e.g., Kreissig et al., 2001), which has not been attempted here.

Several problems remain with geophysical investigations of the NMZ. The recent results are tantalizing because they rest on a single station in the NMZ. A more robust assessment of the lower crustal composition and shear-wave-splitting fast direction in the NMZ would be most useful. A better knowledge of the deep crustal structure of the North Limpopo Thrust Zone and the Triangle Shear Zone could have implications for understanding the whole Limpopo Belt; a deep seismic reflection profile would be invaluable for global comparisons.

In order to test and refine the roles of diapirism and convection in the NMZ, detailed field studies to document the diagnostic criterion for diapirism (e.g., England, 1990; Jelsma et al., 1993; Paterson and Vernon, 1995) are needed. Relating the metamorphic textures to material paths in and around a diapir would be particularly informative, especially given the widespread observations of two stages of granulite facies metamorphism in the NMZ.

\section{CONCLUSIONS}

The charnonenderbite suite of rocks in the Northern Marginal Zone of the Limpopo Belt are granulites that crystallized directly from magma between 2.74 and $2.57 \mathrm{Ga}$. The exceptionally high-heat-producing composition of NMZ rocks led to diapirism, which produced a variety of P-T conditions and paths. Additional heat input may have been supplied from mantle intrusions. The NMZ shows considerable similarities with the 
Zimbabwe Craton in terms of rock types, timing of late Archean igneous events, and the diapiric record, yet by contrast it records pervasive late Archean shortening in a uniform north-northwest direction, which occurred in association with the exhumation of granulites. The $\mathrm{Nd}$ isotopic record suggests that the magmatic rocks were formed by mixing of preexisting crust and mantle, but the oldest well-constrained intrusive date so far obtained from the $\mathrm{NMZ}$ is $2.74 \mathrm{Ga}$. The difference between the craton and the NMZ in the late Archean may therefore reflect the greater strength of the craton because it had a larger component of early crust, and indeed obvious geophysical differences between the NMZ and the craton are confined to the crust: The mantle underneath both the NMZ and the craton is a tectosphere. A lack of gravitational collapse features, implying a lack of overthickening, may have been a distinctive feature of the type of Archean orogenesis represented by the NMZ. The NMZ was affected in localized zones by amphibolite to greenschist facies retrogression and transpressive deformation at $2.0 \mathrm{Ga}$, but intense effects of this event took place only in the south part of the NMZ.

\section{ACKNOWLEDGMENTS}

Numerous colleagues have made important contributions to NMZ geology, not always completely reflected in the reference list. The following especially should be acknowledged: Michael Berger, Victor Chiwara, Paul Dirks, Roebi Frei, Oswald Gwavava, Laurence Holzer, Hielke Jelsma, Shepherd Kadzviti, Balz Kamber, Jan Kramers, Alex Kisters, Joachem Kolb, Martin Mushayandebvu, Siyanda Mwkeli, Martin Prendergast, Hugh Rollinson, Andreas Schmidt Mumm, Peter Treloar, and Jim Wilson. Hugh Rollinson and Paul Dirks provided incisive reviews. Bill Collins, Michael Rubenach, and editor Steve McCourt also provided helpful comments.

\section{REFERENCES CITED}

Barton, J.M., Jr., Holzer, L., Karnber, B., Doig, R., Kramers, J.D., and Nyfeler, D., 1994, Discrete metamorphic events in the Limpopo belt, southern Africa: Implications for the application of P-T paths in complex metamorphic terrains: Geology, v. 22, p. 1035-1038, doi:10.1130/0091-7613 (1994)022<1035:DMEITL>2.3.CO;2.

Belton, D.X., 2006, The low temperature chronology of cratonic terrains [Ph.D. thesis]: University of Melbourne, $403 \mathrm{p}$.

Berger, M., and Rollinson, H., 1997, Isotopic and geochemical evidence for crust-mantle interaction during late Archaean crustal growth: Geochimica et Cosmochimica Acta, v. 61, p. 4809-4829, doi:10.1016/S0016 -7037(97)00271-8.

Berger, M., Kramers, J.D., and Nägler, T.F., 1995, Geochemistry and geochronology of charnoenderbites in the northern marginal zone of the Limpopo Belt, Southern Africa, and genetic models: Schweizerische Mineralogische und Petrographische Mitteilungen, v. 75, p. 17-42.

Blenkinsop, T.G., and Frei, R., 1996, Archean and Proterozoic mineralization and tectonics at the Renco Mine (northern marginal zone, Limpopo Belt, Zimbabwe): Economic Geology and the Bulletin of the Society of Economic Geologists, v. 91, p. 1225-1238.

Blenkinsop, T.G., and Frei, R., 1997, Archaean and Proterozoic mineralization and Tectonics at the Renco Mine (NMZ, Limpopo Belt), Zimbabwe: Economic Geology and the Bulletin of the Society of Economic Geologists, v. 92 , p. $746-747$.
Blenkinsop, T.G., and Kisters, A.F.M., 2005, Steep extrusion of late Archaean granulites in the Northern Marginal Zone, Zimbabwe; evidence for secular change in orogenic style, in Gapais, D., Brun, J.P., and Cobbold, P.R., eds., Deformation Mechanisms, Rheology and Tectonics: From Minerals to the Lithosphere: Geological Society [London] Special Publication 243, p. 193-204, doi:10.1144/GSL.SP.2005.243.01.14.

Blenkinsop, T.G., and Mkweli, S., 1992, The relationship between the Zimbabwean craton and the North marginal zone of the Limpopo Belt: Proceedings of the Second Symposium of Science and Technology, Research Council of Zimbabwe, v. 3C, p. 236-248.

Blenkinsop, T.G., and Wilson, J.F., 1997, The Limpopo Belt of Zimbabwe: Field Trip Guide: Geological Society of Zimbabwe, 22 .

Blenkinsop, T.G., Mkweli, S., Rollinson, H.R., Fedo, C.M., Paya, B.K., Kamber, B., Kramers, J., and Berger, M., 1995, The North Limpopo Thrust Zone: The Northern Boundary of the Limpopo belt in Zimbabwe and Botswana., in Barton, J.R., and Copperthwaite, Y.E., eds., Centennial Geocongress, Volume II: Johannesburg, Geological Society of South Africa, p. 174-177.

Blenkinsop, T.G., Martin, A., Jelsma, H., and Vinyu, M., 1997, The Zimbabwe Craton: Summary of Greenstone Belt geology, in de Wit, M.J., and Ashwal, L.D., eds., Greenstone Belts: Oxford, UK, Oxford Monographs on Geology and Geophysics, Oxford University Press, p. 567-580.

Blenkinsop, T.G., Kroner, A., and Chiwara, V., 2004, Single stage, late Archaean exhumation of granulites in the Northern Marginal Zone, Limpopo Belt, Zimbabwe, and relevance to gold mineralization at Renco mine: South African Journal of Geology, v. 107, p. 377-396, doi:10.2113/107.3.377.

Brandl, G., 1995, Geology of the Limpopo Belt and Environs: Contribution to "A Field Workshop on Granulites and Deep Crustal Tectonics, 1990": Johannesburg, Council for Geoscience, map on 2 sheets, scale 1:500,000.

Brun, J.P., Gapais, D., and Le Theoff, B., 1981, The mantled gneiss domes of Kuopio (Finland): Interfering diapirs: Tectonophysics, v. 74, p. 283-304, doi:10.1016/0040-1951(81)90194-3.

Choukroune, P., Bouhallier, H., and Arndt, N.T., 1995, Soft lithosphere during periods of Archean crustal growth or crustal reworking, in Coward, M.P., and Ries, A.C., eds., Early Precambrian Processes: Geological Society [London] Special Publication 95, p. 67-86, doi:10.1144/GSL .SP.1995.095.01.05.

Collins, W.J., 2002, Hot orogens, tectonic switching and creation of continental crust: Geology, v. 30, p. 535-538, doi:10.1130/0091-7613 (2002) $030<0535$ : HOTSAC $>2.0 . \mathrm{CO} ; 2$.

Collins, W.J., and Van Kranendonk, M.J., 1998, Partial convective overturn of Archaean crust in the east Pilbara Craton, Western Australia: Driving mechanisms and tectonic implications: Journal of Structural Geology, v. 20, p. 1405-1424, doi:10.1016/S0191-8141(98)00073-X.

Collins, W.J., and Van Kranendonk, M.J., 1999, Model for the development of kyanite during partial convective overturn of Archean granite-greenstone terranes: The Pilbara craton, Australia: Journal of Metamorphic Geology, v. 17, p. 145-156, doi:10.1046/j.1525-1314.1999.00187.x.

Coward, M.P., and Fairhead, J.D., 1980, Gravity and structural evidence for the deep structure of the Limpopo Belt, southern Africa: Tectonophysics, v. 68 , p. 31-43, doi:10.1016/0040-1951(80)90007-4.

Coward, M.P., and Treloar, P.J., 1990, Tibetan models for Archean tectonics in southern Africa: The Limpopo Belt: A field workshop on granulites and deep crustal tectonics: Johannesburg, Department of Geology, Rand Afrikaans University, p. 35-38.

Coward, M.P., Graham, R.H., James, P.R., and Wakefield, J., 1973, A structural interpretation of the northern margin of the Limpopo orogenic belt, southern Africa: Philosophical Transactions of the Royal Society of London: Ser. A, v. 273, p. 487-491.

Coward, M.P., James, P.R., and Wright, L., 1976, Northern margin of the Limpopo mobile belt, southern Africa: Geological Society of America Bulletin, v. 87, p. 601-611, doi:10.1130/0016-7606(1976)87<601:NMOTLM> 2.0.CO;2.

Cox, K.G., Johnson, R.L., Monkman, L.J., Stillman, C.J., Vail, J.R., and Wood, D.N., 1965, The geology of the Nuanetsi igneous province: Philosophical Transactions of the Royal Society of London, v. A257, p. 71-218.

de Wit, M.J., Roering, C., Hart, R.J., Armstrong, R.A., De Ronde, C.E.J., Green, R.W.E., Tredoux, M., Peberdy, E., and Hart, R.A., 1992, Formation of an Archean continent: Nature, v. 357, p. 553-562.

Dougherty-Page, J.S., 1994, The evolution of the Archean continental crust of northern Zimbabwe [Ph.D. thesis]: Milton Keynes, UK, Open University, 215 p. 
Duncan, A.R., Erlane, A.J., and Marsh, J.S., 1984, Regional Geochemistry of the Karoo Igneous Province, in Erlank, A.J., ed., Petrogenesis of the Volcanic Rocks of the Karoo Igneous Province: Geological Survey of South Africa Special Publication 13, p. 355-368.

Ellis, D.J., 1992, Precambrian tectonics and the physicochemical evolution of the continental crust, II, Lithosphere delamination and ensialic orogeny: Precambrian Research, v. 55, p. 507-524, doi:10.1016/0301-9268(92)90042-M.

England, R.W., 1990, The identification of granitic diapirs: Journal of the Geological Society [London], v. 147, p. 931-933, doi:10.1144/ gsjgs.147.6.0931.

Fedo, C.M., Eriksson, K.A., and Blenkinsop, T.G., 1995, Geologic history of the Archean Buhwa greenstone belt and surrounding granite-gneiss terrane, Zimbabwe, with implications for the evolution of the Limpopo Belt: Canadian Journal of Earth Sciences, v. 32, p. 1977-1990.

Fouch, M.J., James, D.E., Vandecar, J.C., and Van Der Lee, S., and the Kaapvaal Seismic Group, 2004, Mantle seismic structure beneath the Kaapvaal and Zimbabwe Cratons: South African Journal of Geology, v. 107, p. 33-44, doi:10.2113/107.1-2.33.

Frei, R., and Kamber, B.S., 1995, Single mineral Pb-Pb dating: Earth and Planetary Science Letters, v. 129, p. 261-268, doi:10.1016/0012-821X (94)00248-W.

Frei, R., Schoenberg, R., and Blenkinsop, T.G., 1999, Geochronology of the late Archaean Razi and Chilimanzi suites of granites in Zimbabwe; implications for the late Archaean tectonics of the Limpopo Belt and Zimbabwe Craton: South African Journal of Geology, v. 102, p. 55-63.

Gerya, T.V., Perchuk, L.L., Maresch, W.V., and Willner, A.P., 2004, Inherent gravitational instability of hot continental crust; implications for doming and diapirism in granulite facies terrains, in Whitney, D.L., Teyssier, C., and Siddoway, C.S., eds., Gneiss Domes in Orogeny: Geological Society of America Special Paper 380, p. 97-115.

Gwavava, O., Swain, C.J., Podmore, F., and Fairhead, J.D., 1992, Evidence of crustal thinning beneath the Limpopo Belt and Lebombo monocline of Southern Africa based on regional gravity studies and implications for the reconstruction of Gondwana: Tectonophysics, v. 212, p. 1-20, doi:10.1016/0040-1951(92)90136-T.

Gwavava, O., Swain, C.J., and Podmore, F., 1996, Mechanisms of isostatic compensation of the Zimbabwe and Kaapvaal cratons, the Limpopo Belt and the Mozambique basin: Geophysical Journal International, v. 127, p. 635-650, doi:10.1111/j.1365-246X.1996.tb04044.x.

Hamilton, W.B., 1998, Archean magmatism and deformation were not the products of plate tectonics: Precambrian Research, v. 91, p. 143-179, doi:10.1016/S0301-9268(98)00042-4.

Hamilton, W.B., 2003, An alternative Earth: GSA Today, v. 13, no. 11, p. 4-12, doi:10.1130/1052-5173(2003), 013<0004:AAE>2.0.CO;2.

Harley, S.D., 1989, The origins of granulites: A metamorphic perspective: Geological Magazine, v. 126, p. 215-247, doi:10.1017/S0016756800022330.

Hickman, M.H., 1976, Geochronological Investigations in the Limpopo Belt and Part of the Rhodesian Craton [Ph.D. thesis]: Leeds, UK, University of Leeds, $188 \mathrm{p}$.

Hickman, M.H., 1978, Isotopic evidence for crystal reworking in the Rhodesian Archean craton, southern Africa: Geology, v. 6, p. 214-216, doi:10.1130/0091-7613(1978)6<214:IEFCRI >2.0.CO;2.

Hickman, M.H., 1984, Rb-Sr Chemical and isotopic response of gneisses in late Archean shear zones of the Limpopo Mobile Belt, Southern Africa: Precambrian Research, v. 24, p. 123-130, doi:10.1016/0301-9268(84)90054-8.

Holzer, L., Frei, R., Barton, J.M., and Kramers, J.D., 1998, Unravelling the record of successive high grade events in the Central Zone of the Limpopo Belt using $\mathrm{Pb}$ single phase dating of metamorphic minerals: Precambrian Research, v. 87, p. 87-115, doi:10.1016/S0301-9268(97)00058-2.

Holzer, L., Barton, J.M., Paya, B.K., and Kramers, J.D., 1999, Tectonothermal history of the western part of the Limpopo Belt; tectonic models and new perspectives: Journal of African Earth Sciences, v. 28, p. 383-402, doi:10.1016/S0899-5362(99)00011-1.

Horstwood, M.S.A., 1998, Stratigraphy, geochemistry and zircon geochronology of the Midlands greenstone belt, Zimbabwe [Ph.D. thesis]: Southampton, UK, University of Southampton, $215 \mathrm{p}$.

Hyndman, R.D., Currie, C.A., and Mazzoti, S.P., 2005, Subduction zone backarcs, mobile belts and orogenic heat: GSA Today, v. 15, no. 2, p. 4-10, doi:10:1130/1052-5173(2005)015<4:SZBMBA>2.0.CO;2.

James, D.E., 2003, Imaging crust and upper mantle beneath southern Africa: The southern Africa broadband seismic experiment: The Lead- ing Edge (Society of Exploration Geophysicists), v. 22, p. 238-249, doi: $10.1190 / 1.1564529$.

James, D.E., and Fouch, M.J., 2002, Formation and evolution of Archean cratons: Insights from southern Africa, in Fowler, C.M.R., Ebinger, C.J., and Hawkesworth, C.J., eds., The Early Earth: Physical, Chemical and Biological Development: Geological Society [London] Special Publication 199 , p. $1-26$.

James, D.E., Fouch, M.J., Vandecar, J.C., and Van Der Lee, S., and the Kaapvaal Seismic Group, 2001, Tectonspheric structure beneath southern Africa: Geophysical Research Letters, v. 28, p. 2485-2488, doi:10.1029/2000GL012578.

James, P.R., 1975, A deformation study across the northern margin of the Limpopo mobile belt, Rhodesia: [Ph.D. thesis]: Leeds, UK, University of Leeds, $303 \mathrm{p}$.

Jelsma, H.A., and Dirks, P.H.G.M., 2002, Neoarchaean tectonic evolution of the Zimbabwe Craton, in Fowler, C.M.R., Ebinger, C.J., and Hawkesworth, C.J., eds., The Early Earth; Physical, Chemical and Biological Development: Geological Society [London] Special Publication 199, p. 183-211, doi:10.1144/GSL.SP.2002.199.01.10.

Jelsma, H.A., Van Der Beek, P.A., and Vinyu, M.L., 1993, Tectonic evolution of the Bindura-Shamva greenstone belt (northern Zimbabwe): Progressive deformation around diapiric batholiths: Journal of Structural Geology, v. 15, p. 163-176, doi:10.1016/0191-8141(93)90093-P.

Jelsma, H.A., Vinyu, M.L., Valbracht, P.J., Davies, G.R., Wijbrans, J.R., and Verdumen, E.A.T., 1996, Constraints on Archean crustal evolution of the Zimbabwe craton: A U-Pb zircon, $\mathrm{Sn}-\mathrm{Nd}$ and $\mathrm{Pb}-\mathrm{Pb}$ whole rock isotopes study: Contributions to Mineralogy and Petrology, v. 124, p. 55-70, doi: $10.1007 / \mathrm{s} 004100050173$.

Jordan, T.H., 1975, The continental tectosphere: Reviews of Geophysics and Space Physics, v. 13, p. 1-12, doi:10.1029/RG013i003p00001.

Kamber, B.S., and Biino, G.G., 1995, The evolution of high T-low P granulites in the Northern Marginal Zone sensu stricto, Limpopo Belt, ZimbabweThe case for petrography: Schweizerische Mineralogische und Petrographische Mitteilungen, v. 75, p. 427-454.

Kamber, B., Blenkinsop, T., Rollinson, H., Kramers, J., and Berger, M., 1992, Dating of an important tectono-magmatic event in the Northern Marginal Zone of the Limpopo Belt, Zimbabwe: first results, in Blenkinsop, T., and Rollinson, H., eds., North Limpopo Field Workshop Field Guide and Abstracts Volume: Harare, University of Zimbabwe, 39 p.

Kamber, B.S., Kramers, J.D., Napier, R., Cliff, R.A., and Rollinson, H.R., 1995a, The Triangle Shear Zone, Zimbabwe, revisited: New data document an important event at $2.0 \mathrm{Ga}$ in the Limpopo Belt: Precambrian Research, v. 70, p. 191-213, doi:10.1016/0301-9268(94)00039-T.

Kamber, B.S., Blenkinsop, T.G., Villa, I.M., and Dahl, P.S., 1995b, Proterozoic transpressive deformation in Northern Marginal Zone, Limpopo Belt, Zimbabwe: Journal of Geology, v. 103, p. 493-508, doi:10.1086/629772.

Kamber, B.S., Biino, G.G., Wijbrans, J.R., Davies, G.R., and Villa, I.M. 1996, Archaean granulites of the Limpopo Belt, Zimbabwe; one slow exhumation or two rapid events?: Tectonics, v. 15, p. 1414-1430, doi:10.1029/96TC00850

Kempen, T., Kisters, A.F.M., Glodny, J., Meyer, F.M., and Kramm, U., 1997, Lode Gold Mineralization under High Grade Metamorphic Conditions: The Renco Gold Mine, Southern Zimbabwe: Terra Nova, v. 9, 549 p.

Kamber, B.S., Frei, R., and Gibb, A.J., 1998, Pitfalls and new approaches in granulite chronometry; an example from the Limpopo Belt, Zimbabwe: Precambrian Research, v. 91, p. 269-285.

Kgaswane, E.M., Nyblade, A.A., Julia, J., Dirks, P.H.G.M., Durrheim, R.J., and Pasyanis, M.E., 2010, Shear wave velocity structure of the lower crust in southern Africa: Evidence for compositional heterogeneity within Archean and Proterozoic terrains: Journal of Geophysical Research, v. 114, B12304, 2009 doi:10.1029/2008JB006217.

Kisters, A.F.M., Kolb, J., and Meyer, F.M., 1997, Archean and Proterozoic mineralization and tectonics at the Renco Mine (northern marginal zone, Limpopo Belt, Zimbabwe): Economic Geology and the Bulletin of the Society of Economic Geologists, v. 92, p. 745-747.

Kisters, A.F.M., Kolb, J., and Meyer, F.M., 1998, Gold mineralization in highgrade metamorphic shear zones of the Renco Mine, southern Zimbabwe: Economic Geology and the Bulletin of the Society of Economic Geologists, v. 93, p. 587-601.

Kisters, A.F.M., Kolb, J., Meyer, F.M., and Hoernes, S., 2000, Hydrologic segmentation of high-temperature shear zones; structural, geochemical and 
isotopic evidence from auriferous mylonites of the Renco Mine, Zimbabwe: Journal of Structural Geology, v. 22, p. 811-829, doi:10.1016/ S0191-8141(00)00006-7.

Kisters, A.F.M., Stevens, G., Dziggei, A., and Armstrong, R., 2003, Extensional detachment faulting and core-complex formation in the southern Barberton granite-greenstone terrain, South Africa; evidence for a 3.2 Ga orogenic collapse: Precambrian Research, v. 127, p. 355-378, doi:10.1016/ j.precamres.2003.08.002.

Kolb, J., Kisters, A.F.M., Hoernes, S., and Meyer, F.M., 2000, The origin of fluids and nature of fluid-rock interaction in mid-crustal auriferous mylonites of the Renco Mine, southern Zimbabwe: Mineralium Deposita, v. 35, p. 109-125, doi:10.1007/s001260050010.

Kolb, J., Kisters, A.F.M., Meyer, F.M., and Siemes, H., 2003, Polyphase deformation of mylonites from the Renco gold mine (Zimbabwe); identified by crystallographic preferred orientation of quartz: Journal of Structural Geology, v. 25, p. 253-262, doi:10.1016/S0191-8141(02)00031-7.

Kramers, J.D., 1988, An open-system fractional crystallization model for very early continental crust formation: Precambrian Research, v. 38, p. 281295, doi:10.1016/0301-9268(88)90028-9.

Kramers, J.D., and Ridley, J.R., 1989, Can Archean granulites be direct crystallization products from a sialic magma layer?: Geology, v. 17, p. 442-445, doi:10.1130/0091-7613(1989)017<0442:CAGBDC>2.3.CO;2.

Kramers, J.D., Kreissig, K., and Jones, M.Q.W., 2001, Crustal heat production and style of metamorphism: A comparison between two Archean high grade provinces in the Limpopo Belt, southern Africa: Precambrian Research, v. 112, p. 149-163, doi:10.1016/S0301-9268(01)00173-5.

Kreissig, K., Thomas, F.N., Kramers, J.D., van Reenen, D.D., and Smit, C.A., 2000, An isotopic and geochemical study of the northern Kaapvaal Craton and the Southern Marginal Zone of the Limpopo Belt: Are they juxtaposed terranes?: Lithos, v. 50, p. 1-25, doi:10.1016/S0024-4937(99)00037-7.

Kreissig, K., Holzer, L., Frei, R., Villa, I.M., Kramers, J.D., Kroener, A., Smit, C.A., and van Reenen, D.D., 2001, Geochronology of the Hout River shear zone and the metamorphism in the Southern marginal zone of the Limpopo Belt, Southern Africa: Precambrian Research, v. 109, p. 145 173, doi:10.1016/S0301-9268(01)00147-4.

Kroener, A., Jaeckel, P., Hofmann, A., Nemchin, A.A., and Brandl, G., 1998, Field relationships and age of supracrustal Beit Bridge Complex and associated granitoid gneisses in the Central Zone of the Limpopo Belt, South Africa: South African Journal of Geology, v. 101, p. 201-213.

Luais, B., and Hawkesworth, C.J., 1994, The generation of continental crust: An integrated study of crust-forming processes in the Archaean of Zimbabwe: Journal of Petrology, v. 35, p. 43-93.

MacGregor, A.M., 1951, Some milestones in the Precambrian of southern Rhodesia: Transactions, Geological Society of South Africa, v. 54, p. 27-71.

MacGregor, A.M., 1953, Precambrian formations of tropical Southern Africa, in Proceedings of the 19th International Geological Congress, vol. 1, Algiers, 1952, p. 39-52.

Marshak, S., 1999, Deformation style way back then: Thoughts on the contrasts between Archean/Paleoproterozoic and contemporary orogens: Journal of Structural Geology, v. 21, p. 1175-1182, doi:10.1016/S0191 $-8141(99) 00057-7$

Mason, R., 1973, The Limpopo mobile belt; southern Africa: Philosophical Transactions of the Royal Society of London, Ser. A, v. 273, p. 463-485.

McCourt, S., and Vearncombe, J.R., 1987, Shear zones bounding the central zone of the Limpopo Mobile Belt, southern Africa: Journal of Structural Geology, v. 9, p. 127-137, doi:10.1016/0191-8141(87)90021-6.

McCourt, S., and Vearncombe, J.R., 1992, Shear zones of the Limpopo Belt and adjacent granitoid-greenstone terranes; implications for late Archaean collision tectonics in Southern Africa: Precambrian Research, v. 55, p. 553-570, doi:10.1016/0301-9268(92)90045-P.

McCourt, S., Kampunzu, A.B., Bagai, Z., and Armstrong, R.A., 2004, The crustal architecture of Archaean terranes in Northeastern Botswana: South African Journal of Geology, v. 107, p. 147-158, doi:10.2113/107.1-2.147.

McKenzie, D., and Priestley, K., 2008, The influence of lithospheric thickness variations on continental evolution: Lithos, v. 102, p. 1-11, doi:10.1016/ j.lithos.2007.05.005.

Mkweli, S., 1997, The Zimbabwe craton-Northern Marginal Zone boundary and the exhumation process of lower crustal rocks [Ph.D. thesis]: Harare, University of Zimbabwe, $171 \mathrm{p}$.

Mkweli, S., Kamber, B., and Berger, M., 1995, Westward continuation of the craton-Limpopo Belt tectonic break in Zimbabwe and new age con- straints on the timing of the thrusting: Journal of the Geological Society [London], v. 152, p. 77-83, doi:10.1144/gsjgs.152.1.0077.

Moorbath S., Wilson J.F., Goodwin R., and Humm M., 1977, Further Rb-Sr age and isotope data on early and late Archean rocks from the Rhodesian Craton: Precambrian Research, v. 5, p. 229-239.

Moore, A., Blenkinsop, T.G., and Cotterill, F., 2009, South African topography and erosion history: Plumes or plate tectonics?: Terra Nova, v. 21, p. 310-315, doi:10.1111/j.1365-3121.2009.00887.x.

Mushayandebvu, M.F., Jones, D.L., and Briden, J.C., 1994, A paleomagnetic study of the Umvimeela Dyke, Zimbabwe: Evidence for a Mesoproterozoic overprint: Precambrian Research, v. 69, p. 269-280, doi:10.1016/0301-9268(94)90091-4.

Muusha, M., and Kopylova, M., 1998, River Ranch Diamond Mine, in Large Mines Field Excursion Guide: Cape Town, International Kimberlite Conference, 7 th, p. 33-37.

Mwatahwa, C., 1992, The geology of the area around Rhonda and the United Mines (Mberengwa) [B.S. honor's thesis]: Harare, University of Zimbabwe, $44 \mathrm{p}$.

Nägler, T.F., Kramers, J.D., Kamber, B.S., Frei, R., and Prendergast, M.D.A., 1997, Growth of the subcontinental lithospheric mantle beneath Zimbabwe started at or before 3.8 Ga: Re-Os study on chromites: Geology, v. 25, p. 983-986, doi:10.1130/0091-7613(1997)025<0983:GOSLMB>2.3.CO;2.

Nair, S.K., Gao, S.S., Liu, K.H., and Silver, P.G., 2006, Southern African crustal evolution and composition: Constraints from receiver function studies: Journal of Geophysical Research, v. 111, B02304, doi:10.1029/2005JB003802.

Nguuri, T.K., Gore, J., James, D.E., Webb, S.J., Wright, C., Zengeni, T.G., Gwavava, O., Snoke, J.A., and the Kaapvaal Seismic Group, 2001, Crustal structure beneath southern Africa and its implications for the formation and evolution of the Kaapvaal and Zimbabwe cratons: Geophysical Research Letters, v. 28, p. 2501-2504, doi:10.1029/2000GL012587.

Niu, F., and James, D.E., 2002, Fine structure of the lowermost crust beneath the Kaapvaal craton and its implications for crustal formation and evolution: Earth and Planetary Science Letters, v. 200, p. 121-130, doi:10.1016/ S0012-821X(02)00584-8

Oberthür, T., Davis, D.W., Blenkinsop, T.G., and Höhndorf, A., 2002, Precise $\mathrm{U}-\mathrm{Pb}$ mineral ages, $\mathrm{Rb}-\mathrm{Sr}$ and $\mathrm{Sm}-\mathrm{Nd}$ systematics for the Great Dyke, Zimbabwe-Constraints on late Archean events in the Zimbabwe craton and Limpopo belt: Precambrian Research, v. 113, p. 293-305, doi:10.1016/S0301-9268(01)00215-7.

Odell, J., 1975, Explanation of the Geological Map of the Country around Bangala Dam: Rhodesian Geological Survey Short Report, v. 42, 46 p.

Partridge, T.C., and Maud, R.R., 1987, Geomorphic evolution of southern Africa since the Mesozoic: South African Journal of Geology, v. 90, p. 165-184.

Paterson, S.R., and Vernon, R.H., 1995, Bursting the bubble of ballooning plutons: A return to nested diapirs emplaced by multiple processes: Geological Society of America Bulletin, v. 107, p. 1356-1380, doi:10.1130/00167606(1995)107<1356:BTBOBP>2.3.CO;2.

Pitfield, P.E.J., 1996, Tectonic Map of Zimbabwe: Geological Survey of Zimbabwe, scale 1:1,000,000, 1 sheet.

Ranganai, R.T., Kampunzu, A.B., Atekwana, E.A., Paya, B.K., King, J.G., Koosimile, D.I., and Stettler, E.H., 2002, Gravity evidence for a larger Limpopo Belt in Southern Africa and geodynamic implications: Geophysical Journal International, v. 149, p. F9-F14, doi:10.1046/j.1365 -246X.2002.01703.X.

Reeves, C., 1978, A failed Gondwana spreading axis in southern Africa: Nature, v. 273, p. 222-223, doi:10.1038/273222a0.

Rey, P., Vanderhaeghe, O., and Teyssler, C., 2001, Gravitational collapse of the continental crust: Definition, regimes and modes: Tectonophysics, v. 342, p. 435-449

Ridley, J.R., 1992, On the origins and tectonic significance of the charnockite suite of the Archaean Limpopo Belt, northern marginal zone, Zimbabwe: Precambrian Research, v. 55, p. 407-427, doi:10.1016/0301-9268(92)90037-O.

Robertson, I.D.M., 1973a, The Geology of the Country around Mount Towla, Gwanda District: Bulletin of the Rhodesian Geological Survey, v. 68, 166 p.

Robertson, I.D.M., 1973b, Potash granites of the southern edge of the Rhodesian craton and the northern granulite zone of the Limpopo Mobile Belt, in Lister, L.A., ed., Symposium on Granites, Gneisses and Related Rocks: Geological Society of South Africa Special Publication 3, p. 265-276.

Robertson, I.D.M., 1974, Explanation of the Geological Map of the Country South of Chibi: Geological Survey of Rhodesia Short Report, v. 41, 40 p. 
Roering, C., van Reenen, D.D., Smit, C.A., Barton, J.M., De Beer, J.H., de Wit, M.J., Stettler, E.H., Van Schalkwyk, J.F., Stevens, G., and Pretorius, S., 1992, Tectonic model for the evolution of the Limpopo Belt: Precambrian Research, v. 55, p. 539-552, doi:10.1016/0301-9268(92)90044-O.

Rollinson, H.R., 1989, Garnet-orthopyroxene thermobarometry of granulites from the northern marginal zone of the Limpopo belt, Zimbabwe, in Daly, J.S., Cliff, R.A., and Yardley, B.W.D., eds., Evolution of Metamorphic Belts: Geological Society [London] Special Publication 43, p. 331-335.

Rollinson, H.R., 1993, A terrane interpretation of the Archaean Limpopo Belt: Geological Magazine, v. 130, p. 755-765, doi:10.1017/ S001675680002313X.

Rollinson, H.R., 1995a, The relationship between chromite chemistry and the tectonic settings of Archean ultramafic rocks, in Blenkinsop, T.G., and Tromp, P., eds., Sub-Saharan Economic Geology: Amsterdam, Balkema, p. 7-23.

Rollinson, H.R., 1995b, Composition and tectonic setting of chromite deposits through time-A discussion: Economic Geology and the Bulletin of the Society of Economic Geologists, v. 90, p. 2091-2092.

Rollinson, H.R., 1997, The Archean komatiite-related Inyala Chromitite, southern Zimbabwe: Economic Geology and the Bulletin of the Society of Economic Geologists, v. 92, p. 98-107.

Rollinson, H., and Blenkinsop, T., 1995, The magmatic, metamorphic and tectonic evolution of the Northern Marginal Zone of the Limpopo Belt in Zimbabwe: Journal of the Geological Society [London], v. 152, p. 65-75, doi:10.1144/gsjgs.152.1.0065.

Rollinson, H.R., and Lowry, D., 1992, Early basic magmatism in the evolution of the northern marginal zone of the Archean Limpopo Belt: Precambrian Research, v. 55, p. 33-45, doi:10.1016/0301-9268(92)90012-D.

Siivola, J., and Schmid, R., 2007, A systematic nomenclature for metamorphic rocks: 12. List of mineral abbreviations: Recommendations by the IUGS Subcommission on the Systematics of Metamorphic Rocks; available at http://www.bgs.ac.uk/scmr/home.html (accessed 1 February 2007).

Silver, P.G., Gao, S.S., Liu, K.H., and the Kaapvaal Seismic Group, 2001, Mantle deformation beneath southern Africa: Geophysical Research Letters, v. 28, p. 2493-2496, doi:10.1029/2000GL012696.

Silver, P.G., Fouch, M.J., Gao, S.S., Schmitz, M., and the Kaapvaal Seismic Group, 2004, Seismic anisotropy, mantle fabric and the magmatic evolution of Precambrian southern Africa: South African Journal of Geology, v. 107, p. 45-58, doi:10.2113/107.1-2.45.

Stankiewicz, J., Chevrot, S., Van Der Hilst, R.D., and de Wit, M.J., 2002, Crustal thickness, discontinuity depth, and upper mantle structure beneath southern Africa: Constraints from body wave conversions: Physics of the Earth and Planetary Interiors, v. 130, p. 235-251, doi:10.1016/S0031 -9201(02)00012-2.

Stuart, G.W., and Zengeni, T., 1987, Seismic crustal structure of the Limpopo mobile belt, Zimbabwe: Tectonophysics, v. 144, p. 323-335, doi:10.1016/0040-1951(87)90300-3.

Taylor, P.N., Kramers, J.D., Moorbath, S., Wilson, J.F., Orpen, J.L., and Martin, A., 1991, Pb-Pb, Sm-Nd and Rb-Sr geochronology in the Archean craton of Zimbabwe: Chemical Geology, v. 87, p. 175-196.

Treloar, P.J., and Blenkinsop, T.G., 1995, Archaean deformation patterns in Zimbabwe; true indicators of Tibetan-style crustal extrusion or not? in
Coward, M.P., and Ries, A.C., eds., Early Precambrian Processes: Geological Society [London] Special Publication 95, p. 87-107, doi:10.1144/ GSL.SP.1995.095.01.06.

Treloar, P.J., Coward, M.P., and Harris, N.B.W., 1992, Himalayan-Tibetan analogies for the evolution of the Zimbabwe craton and Limpopo Belt: Precambrian Research, v. 55, p. 571-587, doi:10.1016/0301-9268(92)90046-Q.

Tsunogae, T., Miyano, T., and Ridley, J.R., 1992, Metamorphic P-T profiles from the Zimbabwe Craton to the Limpopo Belt, Zimbabwe: Precambrian Research, v. 55, p. 259-277, doi:10.1016/0301-9268(92)90027-L.

Van Breemen, O., and Dodson, M.H., 1972, Metamorphic Chronology of the Limpopo Belt, Southern Africa: Geological Society of America Bulletin, v. 83, p. 2005-2018, doi:10.1130/0016-7606(1972)83[2005:MCOTLB] 2.0.CO;2.

Van Breemen, O., and Hawkesworth, C.J., 1980, Sm-Nd isotopic study of garnets and their metamorphic host rocks: Transactions of the Royal Society of Edinburgh, v. 71, p. 97-102.

van Reenen, D.D., Barton, J.M., Jr., Roering, C., Smith, C.A., and Van Schalkwyk, J.F., 1987, Deep crustal response to continental collision: The Limpopo belt of southern Africa: Geology, v. 15, p. 11-14, doi:10.1130/0091 -7613(1987)15<11:DCRTCC >2.0.CO;2.

Van Zijl, J.S.V., 1978, The relationship between deep electrical resistivity and structure and tectonic provinces in southern Africa. Part I. Results obtained by Schlumberger soundings: Transactions of the Geological Survey of South Africa, v. 81, p. 129-142.

Weinberg, R.F., 1997, Diapir-driven crustal convection: Decompression melting, renewal of magma source and the origin of nested plutons: Tectonophysics, v. 271, p. 217-229, doi:10.1016/S0040-1951(96)00269-7.

White, D.J., Musacchio, G., Helmstaedt, H.H., Harrap, R.M., Thurston, P.C., van der Velden, A., and Hall, K., 2003, Images of a lower-crustal oceanic slab: Direct evidence for tectonic accretion in the Archean western Superior province: Geology, v. 31, p. 997-1000, doi:10.1130/G20014.1.

Wilson, J.F., 1990, A craton and its cracks: Some of the behaviour of the Zimbabwe block from the Late Archaean to the Mesozoic in response to horizontal movements, and the significance of some of its mafic dyke fracture patterns: Journal of African Earth Sciences, v. 10, p. 483-501, doi:10.1016/0899-5362(90)90101-J.

Wilson, J.F., Jones, D.L., and Kramers, J.D., 1987, Mafic Dyke Swarms of Zimbabwe, in Halls, H.C., and Fahrig, W.F., eds., Mafic Dyke Swarms: Geological Society of Canada Special Paper 34, p. 433-444.

Wilson, J.F., Nesbitt, R.W., and Fanning, C.M., 1995, Zircon geochronology of Archaean felsic sequences in the Zimbabwe craton: A revision of greenstone stratigraphy and a model for crustal growth, in Coward, M.P., and Ries, A.C., eds., Early Precambrian Processes: Geological Society [London] Special Publication 95, p. 109-126, doi:10.1144/GSL .SP.1995.095.01.07.

Worst, B.G., 1962, The Geology of the Buhwa Iron Ore Deposits and Adjoining Country: Belingwe District: Bulletin of the Geological Survey of South Rhodesia, v. 53, 114 p.

Manuscript AcCePted By the Society 24 May 2010 
